\title{
INDUSTRI PENGOLAHAN MINYAK BUMI DI INDONESIA
}

\author{
Andriati Fitria Wati, Elvina Yulistia Erwan, Nur \\ Azizah,PamelaJurdilla
}

Mahasiswa Kimia, FMIPA, Universitas Negeri Padang, Indonesia

*Email :andriatifitria99@gmail.com

\begin{abstract}
Abstrak.Tujuan dari pembuatan artikel ini adalah untuk menjelaskan dan memaparkan secara umum tentang perusahaan minyak bumi di Indonesia, proses pengolahan serta dampak dari minyak bumi. Metode yang digunakan adalah analisa kualitatif dengan pendekatan deskriptif dari kajian kepustakaan. Indonesia merupakan negara penghasil minyak bumi terbesar di dunia. Adapun 7 provinsi penghasil minyak mentah terbesar di Indonesia ialah Sumatera Selatan, Kepulauan Riau, Papua Barat, Sektor Laut Jawa, Riau, Jawa Timur, dan Kalimantan Timur. Proses dalam pengolahan minyak bumi diantaranya, destilasi, cracking, alkilasi, reforming dan polimerisasi, treating, serta blending. Dengan berbagai proses tersebut minyak bumi yang diolah dapat menghasilkan produk yang bermanfaat. Selain dampak positif dari minyak bumi, ada juga dampak negatifnya terhadap lingkungan sekitar.
\end{abstract}

Kata kunci: Minyak Bumi, Proses, Industri, Perusahaan, Dampak 


\section{Pendahuluan}

Minyak bumi ${ }^{[1-2]}$ juga dapat disebut petrolium ${ }^{[3]}$ yang asalnya dari bahasa yunani yaitu dari kata petrus danoleumserta jugaoleus, petrus adalah batu \&oleus adalah minyak. Minyak bumi merupakan ${ }^{[4]}$ cairan kental coklat kehitaman yang tersusun oleh beberapa senyawa hidrokarbon ${ }^{[5-7]}$ yang tersusun secara kompleks.Seperti yang kita ketahui bahwasannya minyak maupun gas bumi ${ }^{[8-10]}$ merupakan sumber salah satu energiyang paling dibutuhkan dalam berbagai bidang sesuai kebutuhannya masing-masing, salah satu penggunaannya yaitu terhadap industri ${ }^{[11-14]}$, transportasi, serta di berbagai bidang kegiatan rumah tangga $^{[15]}$. Ada yang menyatakan bahwa, konversi dari energi cahaya dapat menghasilkan energi listrik, dimana tidak mendapatkan sisa hasil buangannya sama halnya seperti pembakaran $\mathrm{BBM}^{[16-19]}$ dan juga hasil dari beberapa bahan bakar fosil ${ }^{[20]}$ yang lain ${ }^{[21-22]}$.Materi sedimen organik dan minyak mentah mengandung berbagai senyawa (biomarker) untuk menentukan jenis senyawa yang terdapat pada organisme tertentu ${ }^{[23]}$.

Menurut teori biogenesis, teori anorganik dan teori duplex bahwasanya jasad renik dari beberapa makluk hidup yang bersumber baik dari tumbuhan,hewan maupun manusia yang merupakan bahan pembentuk minyak bumi. Kumpulan jasad dari makluk hidup akan dibawa oleh air sungai bersama dengan lumpur yang akan berkumpul di dasar laut. Waktu yang dibutuhkan pada peristiwa tersebut sangat lama bahkan mencapai ribuan tahun. Selain itu, juga dipengaruhi oleh suhu dan tekanan sampai akhirnya jasad dari makluk hidup tersebut atau renik, menjadi bintik-bintik dan gelembung-gelembung gas dan minyak.

Teori anorganik mengatakan bahwa minyak bumi terbentuk akibat aktivitas bakteri terhadap senyawa atau unsur yang terkubur akibat aktivitas bakteriseperti oksigen, belerang, dan nitrogen yang berubah menjadi zat hidrokarbon dalam kandungan minyak bumi. Menurut teori duplex minyak bumi atau gas alam terbentuk dari gabungan teori organik dan anorganik. Dimana terdiri dari berbagai jenis organisme makluk hidup, baik hewan dan tumbuhan di laut, yang kemudian menjadi tumpukan sedimen atau batuan lunak yang dikenal dengan batu induk. Batuan induk terbentuk oleh pengaruh waktu, temperatu dan tekanan. Bintik-bintik dan gelembung-gelembung minyak dan gas bergerak menuju tempat yang bertekanan rendah, kemudian terkumpul pada daerah perangkap (trap). Di daerah tersebutlah gas alam, air dan minyak terkumpul menjadi endapan minyak bumi.

Didalam setiap perangkat Trap akan memiliki kandungan yang berbedabeda. Pada Trap pertama terdiri atas minyak, gas, dan air, Trap kedua terdiri dari minyak dan air, sedangkan pada Trap ketiga terdiri dari gas dan air. Keberadaan minyak, gas di bumi juga berbeda-beda, hal ini dipengaruhi oleh perbedaan berat jenis dari minyak, gas dan air. Dimana gas berada pada bagian atas, minyak pada bagian pertengahan sedangkan air pada bagian bawah.

Adapun proses terbentuknya minyak bumi melalui beberapa tahapan, pada tahapan pertama yaitu fotosintesa ganggang. Ganggang merupakan salah satu biota terpenting dalam menghasil minyak bumi. Hal ini terjadi apabila ganggang yang tidak lagi berfotosintesa dengan air maka akan mati dan membentuk batuan induk. Sedangkan untuk tumbuhan yang berbijiatau yang disebut tingkat tinggi apabila tidak mengalami fotosintesa lagi maka akan mati. Dimana mereka akan 
sering menproduksi kandungan gas dari pada minyak bumi. Tahapan kedua, pembentukan batuan induk yang mana terbentuk dari ganggang yang telah mati, kemudian mengalami pengendapan didasar laut sehingga terbentuk batuan induk. Senyawa karbon terkandung didalam batuan induk yang terbentuk. Karbon yang terbentuk dari ganggang melalui proses yang spesifik, sehingga tidak semua cekungan bisa terbentuk menjadi batuan induk.

Tahapan ketiga, pengendapan batuan induk yang akan tertimbun oleh batuan lain selam jutaan tahun. Adapun batuan yang menimbun batuan induk disebut juga batuan sarang yang pada umumnya terbentu dari batu gamping, pasir dan batu vulkanik. Semakin lama maka batuan yang menumpuk akan semakin banyak, hal ini membuat batuan induk pada dasarnya akan tertekan kedalam sehingga suhu didalam akan semakin tinggi. Pada suhu 50-180 derajat celsius maka minyak akan terbentuk. Tahapan keempat adalah terbentuknya hidrokarbon dari reaksi perubahan karbon dengan hidrogen.Perubahan yang terjadi menghasilkan minyak mentah yang mana berupa cairan dengan memiliki kekentalan. Minyak mentah memiliki kekentalan yang lebih tinggi atau lebih kental dibandingkan air, namun minyak mentah memiliki densitas atau berat jenis yang lebih rendah dari pada air. Hal ini terbukti dariletak minyak mentah di bumi yang man di pertengahan air dan gas.

Berdasarkan keterangan diatas tampak jelas bahwasannya minyak bumi merupakan ${ }^{[24]}$ salah satu sumber kekayaan yang terletak didalam perut bumi, dimana bahan tersebut dapat kita ambil dari bahan galian yang sangat berpengaruh tajam bagi keadaan ekonomi serta politik diberbagai Negara ${ }^{[25]}$. Seiring meningkatnya kebutuhan BBM atau bahan bakar minyak ${ }^{[26]}$ dapat mengakibatkan turunnya berbagai cadangan yang menggunakan bebagai bahan fosil ${ }^{[27]}$. Di berbagai daerah terutama Indonesia, Pengusaha gas bumi ${ }^{[28]}$ yang terletak dibagian sisi hilir Indonesia masih cenderung dimiliki oleh berbagai perusahaan minyak bumi serta gas yang dimiliki oleh Negara yaitu (pertamina) yang bertugas untuk melakukan usahanya di bidang integrasi secara vertikal, di mana tugasnya terhitung dari ujung sisi hulu hingga tersebar hingga sisi hilir ,yang masi mencakup urusan tentang minyak bumi ${ }^{[29]}$.

Indonesia masih mengutamakan pemanfaatan energi berbahan bakar fosil ${ }^{[30]}$, terkhusus untuk bahan bakar minyak yang telah menjadi salah satu sumber energi serta pemenuhan sumber devisa bagi Negara ${ }^{[31]}$. Sekitar tahun 1974 indonesia memiliki ${ }^{[32]}$ cadangan minyak ${ }^{[33]}$ yang lumayan tinggi sebesar 15.000 metrik barel atau yang di kenal (MB) serta dan pada tahun 2000-an indonesia memiliki pasokan cadangan minyak sekitaran 5123 metrik barel (MB) dan terakhir pada tahun 2004 cadangan yang di miliki sekitar $4301 \mathrm{MB}^{[34]}$. Dapat di ketahui perubahan dalam harga dapat berpengaruh besar terhadap dunia ${ }^{[35]} \mathrm{dan}$ dapat menggerakkan beberapa harga saham yang ada di dunia ${ }^{[36]}$. Semakin berkembangnya zaman, semakin banyak metode yang digunakan dalam mensintesis suatu material ${ }^{[37]}$. Jadi, minyak bumi merupakan campuran heterogen yang tersusun atas senyawa kimia yang diolah dari minyak mentah menjadi produk yang bisa digunakan masyarakat. Penyusun minyak bumi umumnya tersusun atas carbon ${ }^{[38-40]} 84-87 \%$ dan hidrogen ${ }^{[41-42]} 11-14 \%$ dan senyawasenyawa $^{[43]}$ lainnya seperti sulfur ${ }^{[44]}$, nitrogen ${ }^{[45-46]}$, dan oksigen ${ }^{[47-50]}$.

Tabel 1. Komposisi Senyawa Minyak Bumi 


\begin{tabular}{cc}
\hline Komposisi & Persen (\%) \\
\hline Carbon (C) & $84-87$ \\
Hidrogen (H) & $11-14$ \\
Surfur (S) & $0-3$ \\
Oksigen (O) & $0-2$ \\
Nitrogen & $0-1$ \\
\hline
\end{tabular}

Senyawa karbon merupakan senyawa yang paling banyak terkandung dalam minyak bumi. Dengan jumlah mencapai $84-87 \%$ hal ni di karenakan senyawa karbon merupakan pembentuk utama minyak bumi. Senyawa penyususn minyak bumi terbanyak kedua dan selanjutnya adalah hidrogen, nitrogen oksigen dan surfur. Dengan persentase jumlah hidrogen 11-14 \%, sedangkan nitrogen 0-1\%, surfur $0-3 \quad \%$ dan oksigen $0-2 \%$. Selain senyawa-senyawa karbon,hidrogen,nitrogen,surfur serta oksigen minyak bumi juga mengandung logam walaupun dalam jumlah yang sedikit, dimana berjumlah $0,01 \%$. Jumlah logam dalam minyak bumi tergantung pada dimana minyak bumi itu terdapat, hal ini dipengaruhi oleh kondisis geologi bumi dan pembentukkan minyak bumi. Gabungan dari unsur karbon dan hidrogen maka akan membentuk senyawa hidrokarbo pada minyak. Sedangkan untuk nitrogen, surfu,oksigen,dan logam dikelompokkan kedalam senyawa non hidrokarbon.

Senyawa hidrokarbon penyusun minyak bumi terdiri dari beberapa jenis, diantaranya parffin,naptena, aromatik dan aspaltena. Pada senyawa hidrokarbon parafin yang mana merupakan senyawa hidrokarbon yang bersifatdengan rumus umu $\mathrm{CnH} 2 \mathrm{n}+2$. Senyawa hidrokarbon parafin bersifat stabil yang mana tidak dapat bereaksi dengan asam sulfat pekat pada suhu kamar. Jumlah atom karbon pada senyawa hidrokarbon parafin adalah 4, dimana pada suhu kamar dan tekanan atmosfer akan bersifat gas. Pada gas alam terdapat metana dan etana sedangkan propana dan butana digunakan pada pembuatan gas elpiji. Untuk atom karbon yang berjumlah 5 sampai dengan 16 pada suhu kamar dan tekan atmosfer berwujud cair yang terdapat pada bensi, solar minyak diesel minyak bakar dan kerosin.

Senyawa hidrokarbon jenuh disebut jugasenyawa hidrokarbon naftena dimana rumus kimia $\mathrm{CnH} 2 \mathrm{n}$. siklopentana dan sikloheksana merupakan senyawa hidrokarbon naftena yang terdapat dalam minyak bumi dengan titik didih yang tinggi. Pada senyawa hidrokarbon aromatik yang mana mempunyai sifat tidsk jenuh dengan rumus umum $\mathrm{CnH} 2 \mathrm{n}-6$. Sifat kimia dari senyawa hidrokarbon aromatik adalah sangat reaktif, dimana dapat mengalami reaksi subtitusi pada suatu reaksi dan dapat dioksidasi menjadi asam.Senyawa hidrokarbon aromatik 
pada suhu rendah memiliki jumlah yang sedikit pada minyak bumi seperti benzena. Pada minyak bumi selain senyawa hidrokarbon aromatik juga terdapat naftalen dan antrasen yang disebut senyawa hidrokarbon poliaromat.

Senyawa nonhidrokarbon didalam minyak bumi biasanya dianggap sebagai pengotor seperti nitrogen.oksigen,surfur,dan logam, hal ini disesbabkan karena memiliki pengaruh yang tidak baik dalam proses pengolahan minyak bumi. Senyawa pengotor ini tidak larut dalam minyak bumi ataupun produk minyak bumi, sehingga pengotor ini dinamakan kedalam pengotor oleofilik, sedangkan pengotor oleofobik seperti air dan garam-garam. Senyawa belerang atau surfur yang terdapat dalam minyak bumi dapat digolongkan sedikit, akan tetapi memiliki efek atau dampak yang besar, karena surfur yang terdapat dalam minyak bumi dapat menimbulkan pencemaran dan korosi seta menurunkan angka oktan.

Untuk pemenuhan produksi minyak tersebut pengimporan $\mathrm{BBM}^{[51]}$ harus di lakukan untuk pengoptimalan kilang minyak yang berada di dalam negeri ${ }^{[52]}$. Jadi, minyak bumi sebagai salah satu komoditas yang memegang peranan penting terutama di bidang perekonomian Indonesia. Minyak bumi ${ }^{[53-55]}$ yang belum diolah hasil dari pertambangan dinamakan juga sebagai crude oil atau minyak mentah. Bahan-bahan utama minyak mentah merupakan campuran kompleks yang terdiri dari rantai hidrokarbon ${ }^{[56]}$.

\section{Metodologi Penelitian}

Metode ${ }^{[57-61]}$ yang digunakan ${ }^{[62-63]}$ dalam pembuatan artikel ini merupakan metode analisa kualitatif dengan pendekatan deskriptif berdasarkan kajian kepustakaan. Dimana dalam metode ini memaparkan tentang industri-industri ${ }^{[64-}$ ${ }^{67]}$ minyak bumi di Indonesia ${ }^{[68]}$, bagaimana cara pengolahan minyak bumi ${ }^{[69]}$, limbah minyak bumi serta dampak dari minyak bumi dan solusinya. Adapun teknik pengumpulan data pada ${ }^{[70]}$ artikel ini adalah data sakunder yaitu data yang bersumber dari bahan pustaka, baik dari buku, jurnal-jurnal ${ }^{[71-72]}$, artikel maupun internet ${ }^{[73]}$.

Metode yang digunakan dalam pengolahan minyak bumi pada dasarnya adalah destilasi. Pada tahap ini komponen minyak bumi akan terpisah menjadi fraksi-fraksi sesuai titik didiihnya. Destilasi yang cocok untuk pengoalahan minyak bumi adalah destilasi bertingkat. Destilasi bertingkat ini prinsipnya didasarkan pemisahan fraksi-fraksi dengan perrbedaan titik didihnya. Fraksi-fraksi tersebut dimurnikan dan dirubah struktur molekulnya, setelah itu dibebaskan dari pengotornya dan terakhir ditambah bahan aditif untuk menjadi produk yang dapat dimanfaatkan oleh masyarakat.Minyak mentah mula-mula dipanaskan dalam sebuah tanur tinggi pada tekanan 1 atm pada suhu $\pm 350^{\circ} \mathrm{C}$. Setelah dipanaskann komponen minyak bumi akan terpisah menjadi fraksi-fraksi berdasarkan perbedaan titik didihnya. Selain destilasi ada proses yang dilakukan agar minyak bumi yang dihasilkan murni dan bebas dari pengotor-pengotornya. Prosesnya setelah destilasi meliputi cracking, reforming, alkilasi dan polimerisasi, treating serta blending. 


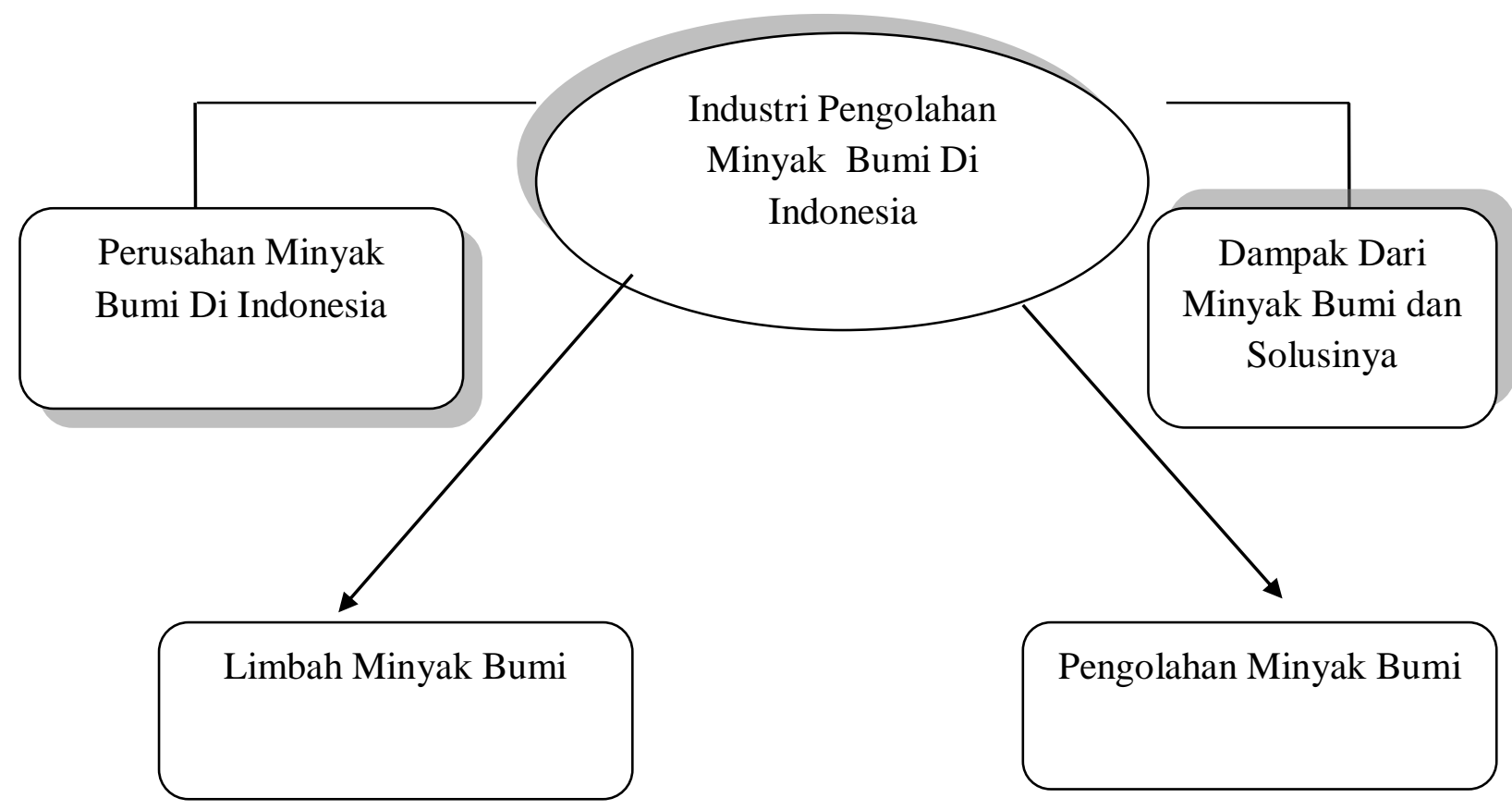

\section{Pembahasan}

3.1. Perusahaan Minyak Bumi di Indonesia

Pengelolaan Minyak bumi oleh perusahan-perusahan Nasional adalah salah satu bentuk aplikasi dari Undang-Undang Dasar 1945 pasal 33ayat $3^{[74-76]}$. Pada tahun 2013 Indonesia menduduki peringkat ke-22 negara dalam penghasil minyak mentah terbesar di dunia, sedangkan pada tahun 2016 Indonesia $^{[77]}$ menduduki peringkat ke-21 negara penghasil minyak mentah terbesar di dunia. Adapun 7 provinsi penghasil minyak mentah terbesar di Indonesia ${ }^{[78-80]}$ ialah Sumatera Selatan,Kepulauan Riau, Papua Barat, Sektor Laut Jawa, Riau,Jawa Timur, dan Kalimantan Timur. 


\section{Pesentase Cadangan Gas Bumi Dunia (\%)}

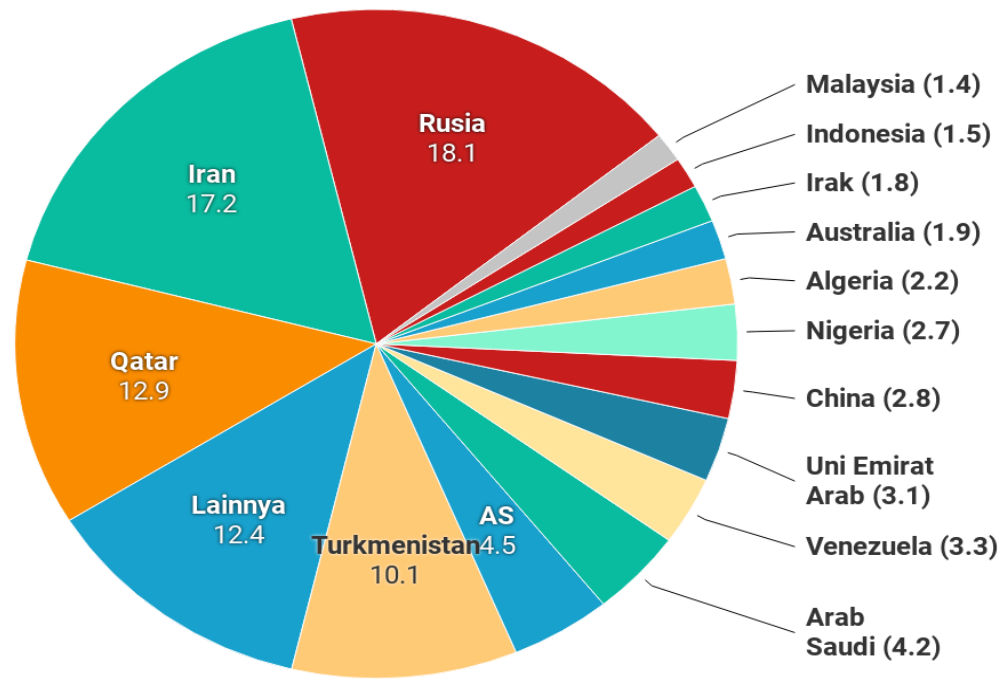

Chart: Raditya Hanung • Source: BP Statistical Review of World Energy 2018

Adapun perusahaan $(\mathrm{PT})^{[81]}$ minyak bumi yang terletak di pulau Jawa adalah PT Pertamina EP Asset,PT CNOOC South East Sumatera LTD, PT Lapindo Brantas INC, PT Pertamina Hulu Energi WMO,PT Santos, PT Kangean Energy Indonesi LTD, dan lain-lain. Perusahaan yang terletak di pulau Papua adalah PT Tangguh LNG, PT Pertamina (PERSERO), PT UP VII Kasim, PT PERTAMINA UP I $^{[82]}$ dan lain-lain.Perusahan yang terletak di pulau Sumatera ${ }^{[83]}$ adalah PT Pertamina Hulu Energi NSB(PHE NSB), PT Petro Selat LTD, PT Kondur Petroleum S.A, PT Chevron Pacific IND, PT Kalila Operatol PTY LTD ,PT TEC Pertamina EP BWP Meruap,PT JOB Pertamina Talisman OK LTD,PT Tiara Bumi Petroleum,PT Conoco Philips, dan alain-lain.Perusahaan yang terletak dipulau Kalimantan adalah PT Badak NGL, PT Pertamina (PERSERO) UP V Balikpapan, dan lain-lain.Berikut penjelasan mengenai beberapa perusahaan minyak bumi yang terbesar di Indonesia, antara lain :

1. Chevron Pasific Indonesia

Chevron Pasifik Indonesia merupakan perusahan pengolahan minyak dan gas terbesar di Indonesia yaitu sekitar 2 miliar barel.Chevron Pasific Indonesia merupakan anak perusahan dari PT Chevron. Chevron sendiri berdiri pada tanggal 10 September 1979 di California, Amerika. Saat ini perusahaan Chevron menjadi perusahaan terintegrasi di seluruh dunia yang tersebar di 180 negara salah satunya di Indonesia.Pada awalnya perusahan Chevron bernama Caltex Pasific indonesia yang kemudian diganti dengan Chevron karena ada pemindahan alih.

Perusahaan ini membawahi empat Production Sharing Contracts (PSC) di area konsesi pada daerah Riau dan Sumutera Utara yang meliputi Duri, Minas, Dumai dan Bekasap. Perusahaan ini bertugas menjadi kontraktor yang berkewajiban menjalankan dan melaksanakan kegiatan operasional serta menyediakan keahlian teknis dan investasi biaya operasi. Sampai saat ini perusahaan Chevron ini menjalani kontrak bagi hasil, yang mana pemabagiannya pertamina mendapatkan $88 \%$ sedangkan Chevroan dan yang lainya mendapatkan $12 \%$. Perusahaan ini termasuk 10 perusahaan yang menyumbang kontribusi produksi terbesar di Indonesia yaitu sebesar 226.000 BOPD. 


\section{Pertamina}

Pertamina merupakan salah satu perusahan badan Usaha Milik Negara (BUMN) dengan tugas untuk megelola minyak bumi dan gas bumi yang ada di indonesia, dimana berdiri sejak tanggal 10 Desember 1957. Pertamina menjalankan kegiatannya berdasarkan prinsip korporasi yang baik sehingga mampu mencapai daya saing tingkat internasional.Perusahaan ini aktif di sektor hilir dan hulu. Sektor hilir mencangkup produksi minyak,energi panas dan gas serta eksplorasi sedangkan sektor hulu meliputi perngolahan dan pemasaran. Pada sektor hulu ini Pertamina melakukan opersaional dan membangun kemitraan bersama Join Operating Bodies (JOB), Join Operating Contract (JOP) dan Technical Assistance Contract (TAC).

Pertamina banyak menghasilkan komoditas yang berguna bagi masyarakat seperti bahan bakar, gas, minyak tanah dan petrokimia. Adapun enam kilang minyak bumi Indonesia sampai sekarang masih dikelola oleh Pertamina dengan memproduksi satu juta bph. Pertamina termasuk perusahaan terbesar memproduksi minyak nomor dua setelah Chevron. Meskipun demikian, Pertamina sepenuhnya perusahaan milik negara sehingga tidak ada saham yang diperdagangkan di Bursa efek Indonesia (BEI). Dalam beberapa tahun terakhir Pertamina mengalami penurunan produksi minyak. Untuk itu Pertamina menggunakan startegi yaitu mengubah fokusnya untuk merangsang pertumbuhan melalui pembelanjaan modal untuk beberapa tahun kedepan. Perusahaan berusaha memperoleh hak ekplorasi minyak di beberapa negara seperti negara timur tengah, Thailand, Burma dan Vietnam dan berusaha meningkatkan produksi dalam negeri dengan menggunakan alat-alat teknologi canggih. Setidaknya Pertamina telah menunjukan kinerja yang baik baik dari sekto hulu maupun hilir.

\section{VICO}

VICO berdiri pada tahun 1972,juga merupakan perusahaan pengolahan minyak terbesar di Indonesia VICO juga melakukan kegiatan dalam pengeboran gas bumi. Pada awalnya VICO bernama Huffco-Huffington Company Indonesia. VICO adalah perusahaan pertama yang membawa LNG ke Indonesia. Minyak dan gas yang saat ini dikelola oleh perusahaan ini dapat memproduksi beberapa aspek diantaranya Badak, Mutiara, Semberah, Nilam Pemaguan, dan Lampake.

Gas alam dikirim ke perusahan pabrik Badak NGL Bontang dimana LNG dan LPG yang dihasilkan dan kemudian dikirimoleh pasokan pupuk metanol di Kaltim industri Estate VICOdan Pertamina ini melakukan kerja sama atas dukungan para mitranya melalui kontrak bagi hasil. Bahkan VICO termasuk penyumbang kontribusi produksi terbesar di Indonesia yaitu sebesar 14.400 BOPD.

\section{Medco E\&P Indonesia}

Perusahaan Medco E\&P Indonesia juga perusahaan yang bergerak disektor minyak yang didirikan pada tanggal 14 Agustus 1968 di daerah sekitar delta Mahakam. Perusahaan Medco E\&P Indonesia adalh anak perusahanPT Medco Energi Internasional,Tbk. Perusahaan ini terdaftar di Bursa Efek Indonesia karena menjalin kerja sama kontrak dengan BP MIGAS. Wilayah kerja perusahaan ini juga berada di beberapa daerah di Indonesia.. Perusahaan ini juga merupakan 
salah satu perusahaan terbesar penyumbang kontribusi terbesar di Indonesia yaitu sekitar 55.100 BOPD.

\section{PHE ONWJ}

PHE ONWJ adalah perusahan yang berdiri sejak tahun 1971, yang melakukan pengolahan minyak dan gas bumi. PHE ONWJ mengolah minyak dan gas bumi pada area lepas pantai. Area tersebut membentang dari Kepulauan Seribu sampai area utara pantai Cirebon. Yang memiliki luas area sekitar 8.300 $\mathrm{km}^{2}$. Perusahaan ini dulunya milik BP West Java dan pada tahun 2009 beralih ke Pertamina. Perusahaan ini ikut mendukung Pertamina sebagai perusahaan nasional kelas dunia dengan melakukan aktivitas untuk mengoptimalisasi produksi minyak dan gas. Pada tahun 2016, target produksi PHE ONWJ adalah 38.000 BOPD dan 165 MMSCFD.PHE ONWJ memiliki tujuan utama yaitu menjalankan standar operasional yang bertaraf internasional, meningkatkan produksi yang efisisen, melakukakan penambahan cadangan dengan diperkuat perkembangan teknologi serta berkomitmen untuk memperkuat pilar-pilar perekonomian nasional yang didukung oleh sumber daya manusiaa yang berkompeten tinggi.

\section{Chevron Indonesia}

Chevron Indonesia adalah perusahaan yang beroperasi di Indonesia yaitu di daerah Blok East Kalimantan yang mengolah minyak dan gas di Indonesia. Perusahaan ini dahulunya bernama Unocal Indonesia kemudian berganti nama menjadi Chevron Indonesia pada tahun 2005. Perusahaan ini merupakan anak perusahaan dari perusaahaan Chevron IndAsia Business Unit. Perusahaan ini juga merupakan perusahaan kontrak dan termasuk perusahaan terbesar penyumbang produsi yaitu sekitar 18.200 BOPD.

\section{CNOOC Indonesia}

CNOOC Indonesia merupakan anak perusahaan CNOOC yang berpusat di Tiongkok. Perusahaan juga termasuk perusaahaan pengolahan minyak bumi dan gas di Indonesia. CNOOC Indonesia merupakan perusahan Kontraktor Kontrak Kerja Sama atau yang dikenal dengan (KKS) yang disetujui oleh BP MIGAS Indonesia agar dapa melaksanakan kegiatan perminyakan dan gas indonesia,yang berdiri sejak tahun 1982.letak dari perusahan CNOOC adalah pada daerah lepas pantai laut Jawa, sektar $90 \mathrm{KM}$ bagian Utara Teluk Jakarta. Perusahaan ini menyumbang produksi pada Indonesia sekitar 30.600 BOPD.

Gambar.1 Wilayah Kandungan MIGAS Di Indonesia 


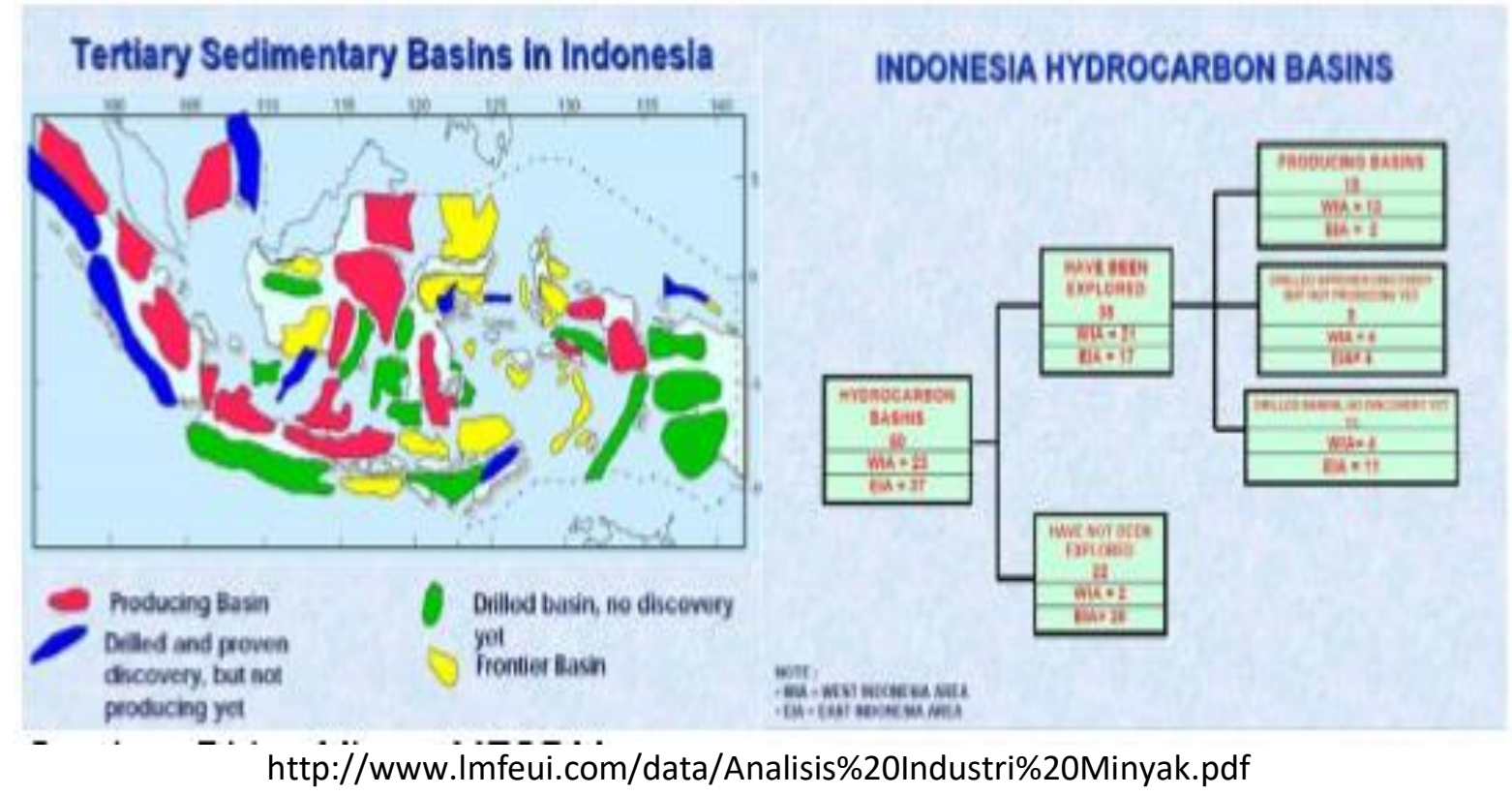

Pada tahun 2018 lifting minyak bumi perusahan di Indonesia mengalami penurunan. Lifting minyak hanya dapat mencapai $96 \%$ yaitu sekitar 770.999 barel per hari (bopd) seharusnya target yang dicapai 800.000 bopd.Perusahan Mobile Cepu Ltd memiliki lifting minyak paling tinggi diantara perusahaanperusahaan minyak lainnya di Indonesia, yaitu sekitar 102,4 \% atau 209.000 bopd. Kemudian dikuti oleh perusahan Chevron dengan lifting minyak mencapai $97 \%$ atau sekitar 207.000 bopd. Dan perusahan-perusahaan lainnya belum mencapai target APBN. Hal ini disebabkan oleh beberapa faktor seperti data yang tidak lengkap, banyak sumur tua, dan masalah SDM.

\subsection{Proses Pengolahan Minyak Bumi di Kilang Minyak}

Pada umumnya pengolahan ${ }^{[84]}$ minyak bumi di Indonesia ${ }^{[85]}$ dikelola oleh kontraktor-kontraktor Asing ${ }^{[86-87]}$. Hal ini disebabkan oleh kurangnya SDM ( sumber daya Manusia) yang kurang memadai. Dimana para kontraktor- kontraktor asing melakukan kontrak kerja dengan perusahan-perusahan Indonesia ${ }^{[88]}$ dengan cara bagi hasil menuruta waktu dan ketentuan yang telah disepakati ${ }^{[89-90]}$. 


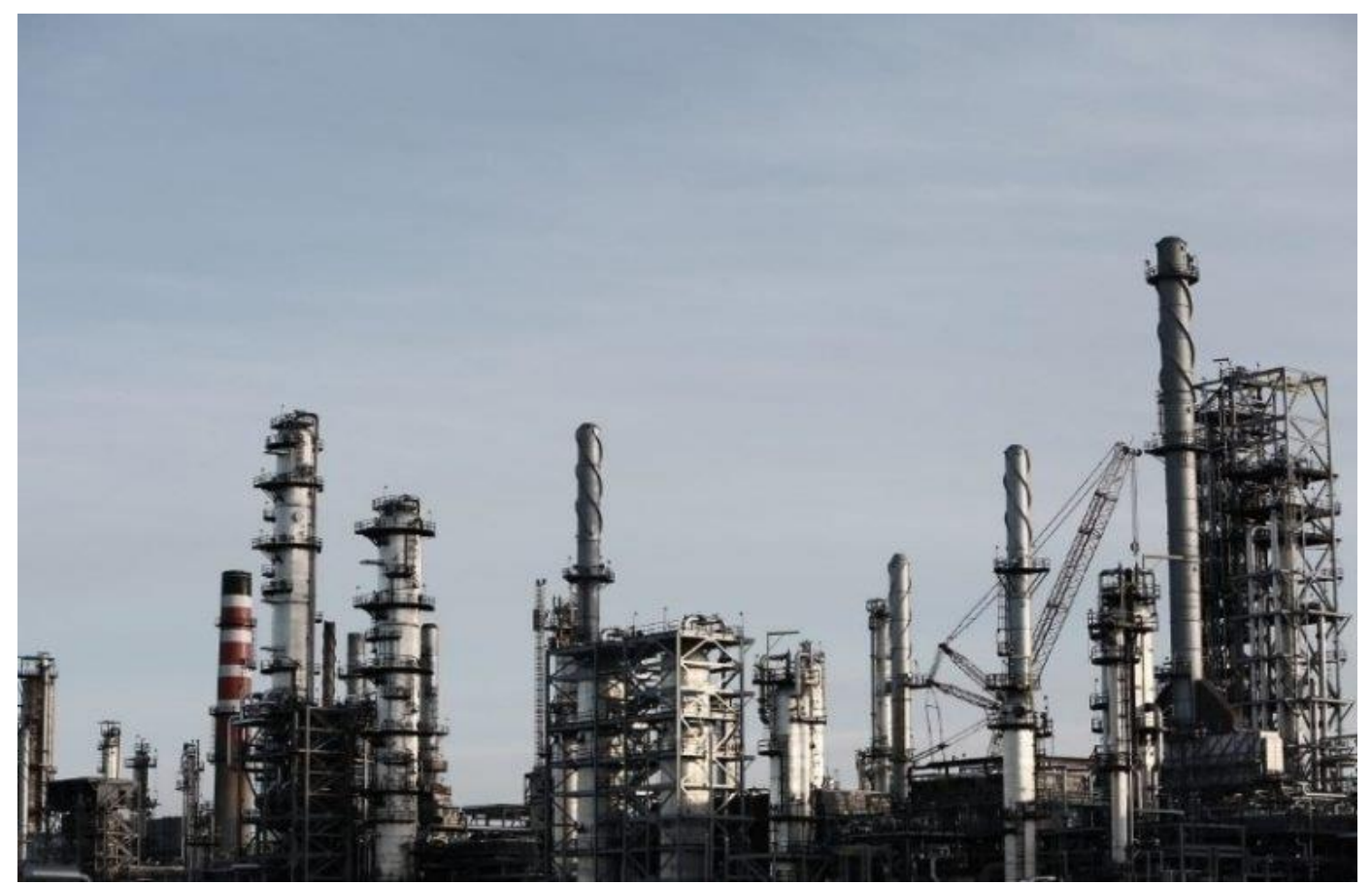

https://www.eduspensa.id/teori-pembentukan-minyak-bumi/\#a

Agar suatu minyak bumi yang diolah dari minyak mentah dapat dikonsumsi oleh masyarakat luas dilakukan beberapa proses ${ }^{[91-92]}$ baik secara fisika maupun kimia. Proses tersebut diperlukan ${ }^{[93]}$ untuk memurnikan dan mengubah struktur dari komponen-komponennya agar diperoleh produk yang bermanfaat ${ }^{[94]}$ bagi konsumen. Dalam pengolaha minyak bumi dapat dihasilkan berbagai produk-produk yang bermanfaat ${ }^{[95]}$ bagi kebutuhan masyarakat ${ }^{[96]}$, diantaranya gas LPG,avtur,avgas, bahan bakar kendara seperti bensun dan solar, minyak tanah dan ${ }^{[97]}$ aspal yang berguna dalam pembuatan jalan.Proses pengolahan minyak bumi biasanya dilakukan di kilang ${ }^{[98]}$ minyak bumi ${ }^{[99]}$.Pada proses kilang minyak bumi adapun bentuk kilang yang dibangun harus disesuaikan dengan jenis pasokan atau jumlah minyak input, dimana dapat memberikanhasil yang lebih bags dengan komposisi yang sesuai ${ }^{[100]}$. Kilang minyak bumi merupakan suatu pabrik yang digunakan untuk mengolah minyak bumi. Pada umumnya, proses pengolahan minyak bumi ${ }^{[101]}$ ada 6 yaitu:

\subsubsection{Proses Destilasi}

Destilasi adalah suatu teknik pemurnian dan pemisahan ${ }^{[102]}$ suatu zat cair berasarkan tingkat volatilitass dan titik didih dari komponen-komponennya. Pada pengolahan minyak bumi, destilasi yang digunakan adalah ${ }^{[103]}$ destilasi bertingkat atau fraksionisasi ini prinsipnya didasarkan pemisahan fraksi-fraksi dengan perrbedaan itik didihnya. Fraksi-fraksi tersebut dimurnikan dan dirubah struktur molekulnya, setelah itu dibebaskan dari pengotornya dan terakhir ditambah bahan aditif untuk menjadi produk yang dapat dimanfaatkan. Minyak mentah mula-mula dipanaskan dalam sebuah tanur tinggi pada tekanan 1 atm pada suhu $\pm 350^{\circ} \mathrm{C}$. Tujuan dari pemanasan dalam pengelolahan ini untuk ${ }^{[104]}$ terpisahnya fraksi-fraksi yang terkandung didalam minyak bumi., Dapat diketahui bahwa semakin rendah titik didih maka fraksitersebut akan terletakdibagian atas pada tanur, sedangkan 
semakin tinggi titik didih maka fraksi tersebut akan terletak dibagian bawah pada tanur. perbedaan titik didih yang akan menyebabkan fraksi ${ }^{[105]}$ akan terpisah. Berikut gambar pemisahan fraksi minyak bumi berdasarkan titik didih yang rendah sampai yang tinggi

Gambar.3 Fraksi Minyak Bumi

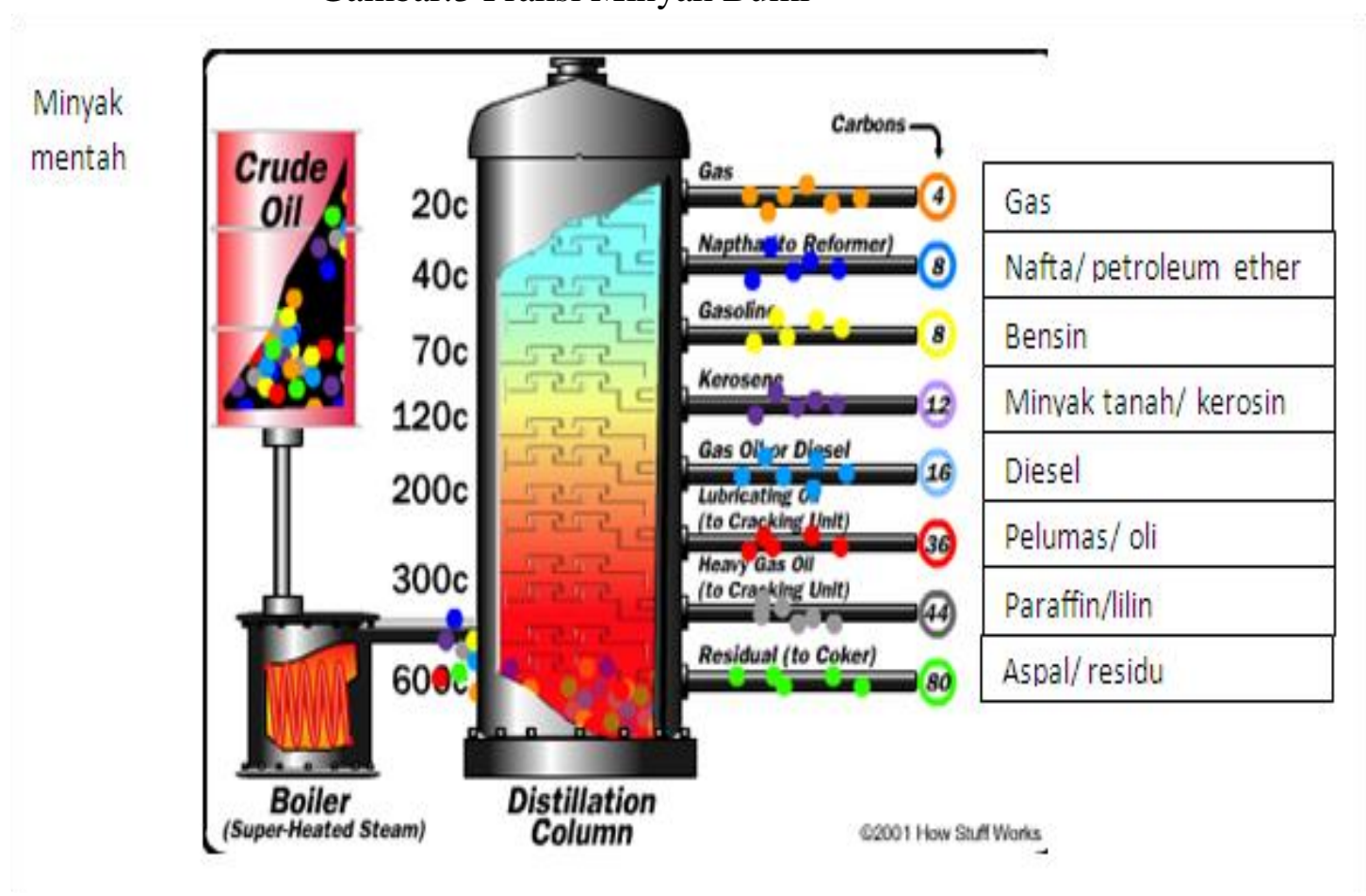

https://id.images.search.yahoo.com/yhs/search

Berdasarkan gambar diatas ada 8 fraksi yang dihasilkan dalam pengolahan minyak mentah secara destilasi. Pada fraksi gas terjadi pada suhu $<30^{\circ} \mathrm{C}$ dengan jumlah atom karbon 1-4. Dimana fraksi gas berfungsi dalam kehidupan sehari hari sebagai gas LPG dan produk petrokimia dalam industri pertokimia. Pada fraksi petroleum ${ }^{[106]}$ eter terjadi pada suhu $30-60^{\circ} \mathrm{C}$ dengan atom karbon 5-6. Adapun kegunaan petroleum eter dalam kehidupan sehari-hari ialah sebagai pelarut non polar dan pelarut bersih.Pada fraksi naftan ${ }^{[107]}$ atau ligronin terjadi pada suhu 60$100^{\circ} \mathrm{C}$ dengan jumlah atom karbon 6-7 bisanya digunakan sebagai zat aditif dan pelarut non polar.

Pada fraksi bensin ${ }^{[108]}$ yang mana terjadi pada suhu $40-200^{\circ} \mathrm{C}$ dengan jumlah atom karbon 5-10 yang berfungsi sebagai bahan bakar ${ }^{[109]}$ kendaraan. Pada fraksi kerosin atau minyak tanah ${ }^{[110]}$ yang mana terjadi pada suhu $175-325^{\circ} \mathrm{C}$ dengan jumlah atom karbon 12-18 yang berfungsi sebagai minyak tanah dan avtur (mesin jet). Pada ${ }^{[111]}$ fraksi solar yang terjadi pada titik didih $250-400^{0} \mathrm{C}$ dengan jumalah atom karbon $>12$ dan berfungsi sebagai penghidup mesin diesel. Pada fraksi oli ${ }^{[112]}$ memiliki titik didih $350-500^{\circ} \mathrm{C}$ dengan atom karbon $>20$ yang biasanya digunakan sebagai minyak pelumas ${ }^{[113-114]}$. Dan terakhir pada fraksi residu $^{[115-117]}$ dengan titik didih $>500^{\circ} \mathrm{C}$ dengan jumlah atom $\mathrm{C}>25$ yang digunakan sebagai lilin, parafin dan aspal. 
Tabel.2 Tahapan pengolahan minyak mentah melaui unit proses menjadi produk

\begin{tabular}{|c|c|c|c|c|}
\hline No & Jenis Proses & Unit Proses & Tujuan Proses & Hasil Akhir \\
\hline 1. & $\begin{array}{l}\text { Pencampuran } \\
\text { minyak bumi }\end{array}$ & $\begin{array}{l}\text { Tangki minyak } \\
\text { bumi }\end{array}$ & $\begin{array}{c}\text { Membuat kualitas } \\
\text { merata }\end{array}$ & $\begin{array}{c}\text { Minyak bumi siap } \\
\text { diolah }\end{array}$ \\
\hline 2. & Persiapan & Desalter & $\begin{array}{l}\text { Menurunkan air } \\
\text { dan menurunkan } \\
\text { garam }\end{array}$ & $\begin{array}{l}\text { Minyak yang siap } \\
\text { di proses }\end{array}$ \\
\hline 3. & $\begin{array}{l}\text { Pemisahan } \\
\text { (Destilasi) }\end{array}$ & $\mathrm{CDU}, \mathrm{HVU}$ & $\begin{array}{l}\text { Pemisihan primer } \\
\text { berdasarkan titik } \\
\text { didh }\end{array}$ & $\begin{array}{l}\text { LPG, naphtha, } \\
\text { kerosene, solar, } \\
\text { LVGo, HVGO, long } \\
\text { residu, short } \\
\text { residu }\end{array}$ \\
\hline 4. & $\begin{array}{l}\text { Konversi } \\
\text { (Cracking } \\
\text { Reforming ) }\end{array}$ & $\begin{array}{c}\text { FCC,RFCC, } \\
\text { Dalayed coker, } \\
\text { Visbreaker, } \\
\text { Platfoming }\end{array}$ & $\begin{array}{l}\text { Perengkahan, } \\
\text { pembentuk/ } \\
\text { reforming }\end{array}$ & $\begin{array}{l}\text { LPG, napthan, } \\
\text { Premiunm, avtur, } \\
\text { solar, Bottoms, } \\
\text { Propylene, Green } \\
\text { Coke }\end{array}$ \\
\hline 5. & $\begin{array}{l}\text { Perbaikan } \\
\text { kualitas }\end{array}$ & HDS & Perbaikan Kualitas & $\begin{array}{c}\text { Solar surfur } \\
\text { Rendah (kualitas } \\
\text { tinggi) }\end{array}$ \\
\hline 6. & $\begin{array}{l}\text { Pencampuran } \\
\text { produk }\end{array}$ & Blending & $\begin{array}{l}\text { Memaksimunkan } \\
\text { merketable produk }\end{array}$ & $\begin{array}{c}\text { LPG, premuin } 88, \\
\text { pertamax pertadex } \\
\text {, fuel oil }\end{array}$ \\
\hline
\end{tabular}

\subsubsection{Cracking}

Prose ${ }^{[118-119]}$ selanjutnya setelah destilasi ialah cracking $^{[120]}$. Cracking atau yang disebut merengkah merupakan proses pembelahan atau penguraian partikelpartikel hidrokabon yang berukuran besar menjadi partikel-partikel hidrokarbon kecil dalam fraksi minyak bumi. Adapun tiga cara yang digunakan dalam proses cracking ialahthermal cracking, catalyc cracking dan hidrocracking. Contohnya ialah pengubahan solar menjadi minyak tanah.

\subsubsection{Reforming}

Reforming merupakan perubahan struktur molekuldari karbon yang rantainya lurus menjadi karbon yang rantainyabercabang dengan adanya bantuan katalis dan pemanasan. Reforming biasanya terjadi pada perubahan mutu bensin dari yang kurang baik menjadi lebih baik walaupun strukturnya berbeda dalam molekul yang sama. 


\subsubsection{Alkilasi dan Polimerasi}

Alkilasi merupakan ${ }^{[121]}$ proses dimana karbon yang rantainya bertambah pada fraksi sehingga molekulnya lebih panjang dan bercabang.Proses alkilasi dilakukan dengan bantuan penambahan katalis ${ }^{[122-125]}$ seperti asam kuat. Sedangkan polimerisasi merupakan proses dimana partikel-partikel kecil bergabung menjadi partikel-partikel yang besar sehingga menghasilkan produk yang bagus.

\subsubsection{Treating}

Treating merupakan proses setelah eliminasi dari pengotor-pengotornya yang kemudian dilakukan pemurnian terhadap fraksi minyak bumi. Pengotorpengotor yang dieliminasi tersebut biasanya berbau ${ }^{[126-127]}$ tidak sedap dengan beberapa proses.

\subsubsection{Blending}

Blending merupakan proses ${ }^{[128]}$ akhir dari pengolahan minyak bumi ${ }^{[129]}$ pada proses ini ditambah zat aditif untuk meningkatkan kualitas akhir dari minyak bumi, contohnya Tetra Ethyl Lead atau TEL yang merupakan zat aditif penambah bilangan oktan bensin.Jadi, blending adalah salah satu teknik atau proses material dimana cara kerjanya dengan menggabungkan atau mencampurkan bahan material dengan jumlah yang telah ditentukan ${ }^{[130]}$.

Bensin merupakan salah satu hasil pengolahan minyak bumi, yang mana berupa cairan yang mana terjadi pada suhu $40-200^{\circ} \mathrm{C}$ dengan jumlah atom karbon 5-10 yang berfungsi sebagai bahan bakar. Bensin dapat diperoleh tidak hanya dengan proses destilasi tetapi juga dengan proses perengkahan, reformasi, polimerisasi, isomerisasi,dan alkilasi dengan melalui pencampuran beberapa komponen serta penambahan zat aditif untuk menaikan mutu bensin.

Pada proses pembuatan bensin dimana menghasilkan gasoline yang belum dapat digunakan, akan tetapi masih perlu penambahan beberapa bahan kimia untuk dicampurkan atau blending dengan gasoline lain. Adanpun pencampuran berguna untuk memperbaiki mutu sehingga aman dalam pemakainannya. Bensi sebagai bahn bakar pada mesian yang menggunakan pembakaran busi yang bercapur dengan udara dalam penggunaan sehingga pencampuran dinyalakan oleh api. Maka dari itu mutu dari pembuatan bensin harus diperhatikan agar menghasilkan pembakaran yang aman dan tidak berbahaya atau merusak lingkungan.

\subsection{Limbah Minyak Bumi}

Pada prosespengolahan minyak mentah atau minyak bumi dimana akan berakibat terjadinya kerusakan atau pencemaran lingkungan. Hal ini disebabkan oleh energi dan bahan baku yang digunakan dalam pengolahan baik melalui proses fisika dan kimia dimana dapat menghasilkan gas karbon monoksida (CO), gas karbon dioksida $\left(\mathrm{CO}_{2}\right)$, uap air dan gas balerang gas oksida. Oleh sebab itu proses pengolahan minyak akan menghasilkan dampak pada lingkungan diantaranya tanah, air dan udara yand disebabkan oleh limbah dan polusi. Limbah yang dihasilkan dari pengolahan ini berupa limbah padat, cair maupun gas, yang mana mempunyai dampak pada lingkungan baik dalam jangka waktu pendek maupun dalam jangka waktu panjang. 
Sumber limbah minyak bumi yang mana berasal dari air sisa sisa kebocoran, terjadinya pembocoran pada pipa-pipa, air sisa umpan boiler, tumpahan dari minyak mentah pada saat proses transportasi,produksi,dan eksporasi. Selain itu pengolahan limbah yang tidak memenuhi baku mutu untuk dibuang ke lingkungan sehingga dapat menimbulkan pencemaran. Adapun salah satu cara untuk mengurangi pencemaran yang terjadi oleh limbah minyak bumi adalah dengan cara mengolah agar sesuai dengan baku mutu lingkungan sehingga dapat diterima oleh lingkungan.

Adapun dampak atau bahaya pencemaran dari limbah minyak bumi yang terjadi dalam jangka pendek adalah ${ }^{[131]}$ menyebabkan kematian pada ikan -ikan di laut. adapun penyebabnya adalah kandungan molekul-molekul hidrokarbon yang terdapat didalam minyak bumi, yang akan berakibat pada struktur dan fungsi tubuh ikan atau binatang laut lainnya. Sedangkan akibat jangka panjang yang ditimbulkan berupa masalah bagi biota muda, diaman hidrokarbon yang terkandung dalam ${ }^{[132]}$ minyak bumi akan diserap oleh biota mudah sehingga membutuhkan waktu yang lama untuk menghilangkan rasa dari hidrokarbon yang menyengat.

Terjadinya gangguan kesehatan pada manusia yang berada atau tinggal di daerah lokasi pertambangan atau pengeboran minyak. Hal ini disebabkan oleh udara dan air dari minyak, yang mana gangguan kesehatannya dapat dibuktikan dalam jangka panjang. Adapun gangguan kesehatan yang muncul ialah pada sistem reproduksi dan penyakit lainnya.

Pengolahan minyak bumi dapat dilakukan kimia, fisika, dan biologis, pengolahan secara fisika biasa dilakukan dengan cara melokasikan tumpahan yang terjadi dan barulah dilanjutakan dengan pengolahan kimia. Sedangkan pengolah biologis dilakukan dengan cara bioremediasi yang mana dengan cara bioteknologi. Dalam metode ini makhluk hidup atau mikroorganisme digunakan ${ }^{[133]}$ untuk mengurangi kadar racun, metode ini merupakan metode yang altenatif dan efektif untuk digunakan.

\subsection{Dampak Penggunaan Minyak Bumi dan Solusinya}

Perkembangan dan kemajuan industri ${ }^{[134-135]}$ di Indonesia semakin meningkat tiap tahunnya. Hal ini memberikan pengaruh yang baiksecara untuk perkembangan ekonomi nasional serta peningkatan taraf hidup sosial masyarakat ${ }^{[136]}$. Namun di sisi lain sektor industri berpotensi menimbulkan pencemaran ${ }^{[137-139]}$ lingkungan ${ }^{[140-141]}$. Salah satu kegiatan industri tersebut yaitu industri minyak dan gas bumi ${ }^{[142-143]}$.

1. Pemanasan global ${ }^{[144]}$

Pada pembakaran minyak bumi terjadinya penambahan gas $\mathrm{CO}_{2}$ di atsmosfer ${ }^{[145]}$, dimana jumlah $\mathrm{CO}_{2}$ akan meningkat di udara sehingga terjadinya pemanasan global. Gas $\mathrm{CO}_{2}$ dihasikan oleh pembakaran bahan bakar fosil yang mana panas matahari dari bumi tidak dapat dipancarkan kembali karena adanya lapisan ozon. Hal ini mengakibatkan terjadinya efek rumah kaca dan peningkatan panas di bumi. Selain itu, akibat pemanasan global juga menimbulkan terjadinya perubahan iklim.

Pemanasan gobal tidak hanaya disebabkan oleh pembakaran minyak bui tetapi juga disebabkan oleh hasil yang diperoleh dari pengolahan tersebut seperti BBM atau bahan bakar minyak. Adapun kegunaan bahan bakar minyak ,tidak 
hanya untuk alat-alat transpotasi tetapi juga digunaka dalam berbagai kebutuhan, sperti elpiji, minyak tanah pada pabrik-pabrik dan sebagai aspal jalan. Dari semua kegunaan produk minyak bumi dapat memberikan damapk bagi pemanasan global dimana tidak hanya menghasilkan gas $\mathrm{CO} 2$ tetapi juga metan dan gas nitrogen yang berdampak pada pemansan global.

Pemanasan global memberikan dampak yang bebahaya bagi lingkungan, dimana pemanasan global tidak hanya disebabkan oleh pembakaran minyak bumi tetapi juga oleh efek rumah kaca. Pemansan global yang terjadi dari tahun ketahun semakin meningkat yang memicu terjadinya hujan asam dan panas yang berlebihan di bumi. Adapu cara untuk menanggulangi pemanasan global adalah dengan cara melakukan reboisaisi atau penhijauan di daerah perkotaan dan sekitar pabrik. Penghijau berguna untuk mengurangi kadar $\mathrm{CO} 2$ di udara sehingga pemansan global berkurang. Selainitu kita juga dapat mengurangi pemakaian kendaraan bermotor, mobil dan lainnya.

2. Ekstrasi ${ }^{[146]}$

Ekstraksi minyak merupakan suatu proses pemindahan minyak bumi dari sumur bor. Biasanya minyak yang telah dipindahkan dalam bentuk emulsi minyak-cair untuk memisahkan minyak dan cair dibutuhkan zat kimia, yang mana zat kimia merusak keseimbangan biota laut.

\section{Pencemaran Air ${ }^{[147-148]}$}

Pencemaran perairan biasanya terjadi akibat tumpahan minyak bumi yang sering terjadi laut, hal ini di sebabkan adanya kebocoran kapal tengker yang mengangkut minyak bumi selain itu penyebab lainya adalah meledaknya anjungan minyak lepas pantai, operasi kapal dan bangunan lepas pantai. Bocornya sistem penampungan atau adanya kapal yang tenggelam menyebabkan tumpahan minyak dilaut sampai ke lepas pantai. Adapun dampak dari pencemaran minyak bumi di lepas pantai,yang penyebaran dipengaruhi oleh gelombang air laut diman mempunya damapk selain pada pantai negara tersebut tetapi juga pada beberapa negara. Pencemaran air atau perairan yang disebabkan oleh tumpahan minyak memiliki pengaruh yang sangat besar terhadap lingkungan di perairan atau laut dengan waktu yang panjang dalam mengatasinya.

Tumpahan minyak yang terjadi ini memiliki dampak pada kerusakan ekosistem dan sumber daya hayati yang berujung panjang. Selain ikan, terumbu karang, rumput laut, magrove, mineral dan sumber daya alam laut lainya. Selain itu hal ini juga berdamapak pada keadan ekonomi masyarakat, dimana masyarakat yang berjerja sebagai nelayan mengalami ganguan atau kesusahan dalam mencari ikan di laut.

Minyak bumi juga memiliki pengaruh bagi biota laut, yang mana tumpahan minyak bumi di laut memiliki dua tipe. Minyak akan larut dala air dan akan mengapung pada permukaan airdan minyak akan tenggelam serta akan mengendap sebagai deposito hitam pada pasir serta batuan pantai. Minyak yang mengaopung mengakibatka warna permukaan air pantai menjadi warna hitam serta dapat mengganggu organisme ang tertdapat di permukaan perairan. Selain itu minyak juga dapat menghambat masuknya cahaya matahari dilaut sehingga oksigen didalam laut berjurang, serta juga dapat menggannggu fotosintesis tumbuhan di dalam laut. Minyak bumi yang tenggelam atau mengendap di dasar laut juga memiliki dampak bagi kehidupan organisme dilaut. Apabila endapan 
tersebut berada pada bibir panati maka akan bepengaruh pada organisme yang hidup pada saat air mengalami pasang surut seperti kepiting.

Minyak bumi yang memiliki komponen atau komposisi kimia, dimana pada saat mengalami pencemaran atau tumpahan pada laut maka akan mengakibatkan perubahan baik secara kimia maupun fisika. Adapun diantara perubahan tersebut akan terjadi penyebaran, pembentukkan lapisan, ada yang menguap, polimerisasi,terjadinya emulsi dan terbentuknya gumpalan. Perubahan yang terjadi didorong oleh gerakan angin gelombang arus dan tegangan dari permukaan. Kandungan hidrokarbon didalam air yang mudah menguap dan apabila terlarut dalam air maka akan membuat lapisan yang tebal.

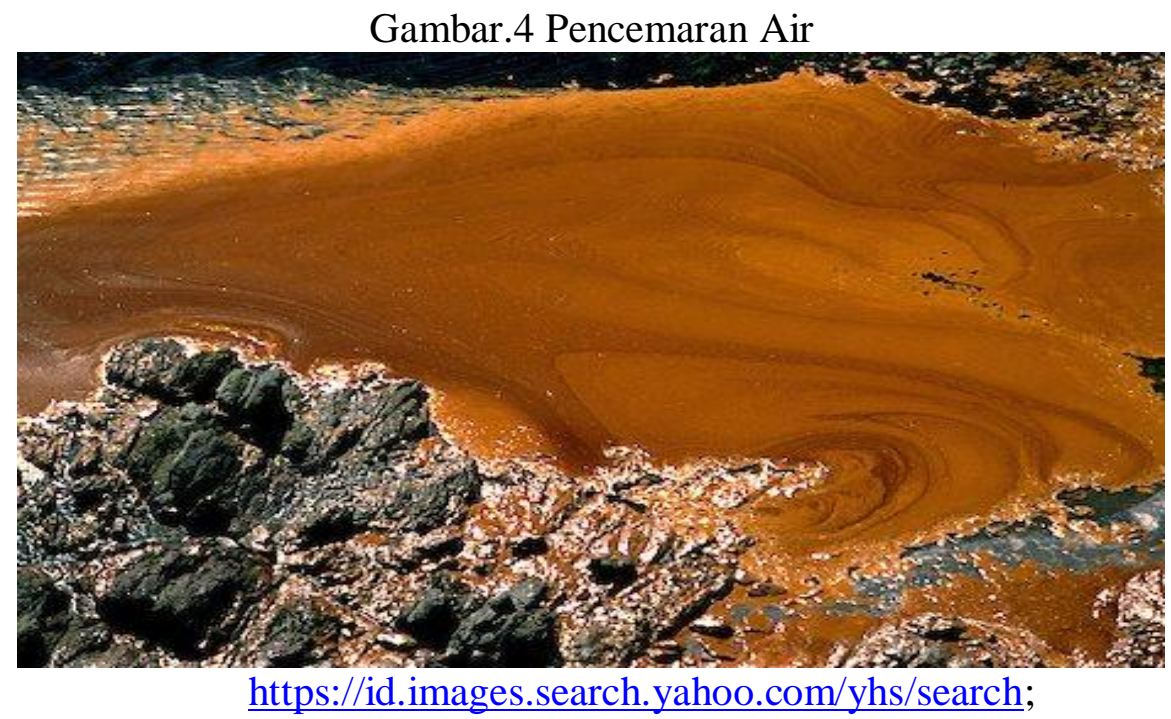

Adapun cara menanggulangi tumpahan minyak di laut dapat dilakukan seperti penyisihan secara mekanis, in-situ burning, teknik bioremediasi, penggunaan sorben dan lainya. Pada teknik bioremediasi untuk tumpahan minyak dilakukan denagan dua tipe yaitu dengan cara menambahkan mikroorganisme pengurai serta menambakan nutrien atau mengubah habitat bakteri pengurai. Salah satu baktei yang digunakan pseudomonas $\mathrm{Sp}$ yang bisa mendegradasi berbagai jenis hidrokarbon

Dalam menimalisir dampak negatif terhadap pemakaian minyak bumi, dapat dilakukan dengan berbagai cara antara lain penghematan dengan menggunakan bahan ramah lingkungan ${ }^{[151]}$, menghemat energi semaksimal mungkin, memproduksi bensin bebas timbal, menproduksi bahan pengganti minyak bumi seperti bioetanol dan biodiesel dan lain-lain. Yang paling utama adalah diperlukan kesadaran diri sendiri untuk menjaga lingkungan agar terbebas dari dampak tersebut.

\section{Kesimpulan}

1. Minyak bumi merupakan cairan kental coklat kehitaman yang tersusun oleh beberapa senyawa hidrokarbon yang tersusun secara kompleks.

2. Minyak bumi yang umumnya tersusun atas carbon $84-87 \%$ dan hidrogen $11-14 \%$ dan senyawa lainnya seperti sulfur, nitrogen dan oksigen. 
3. Beberapa perusahan minyak bumi terbesar dan terkenal di Indonesia diantaranya Chevron, Pertamina, VICO dan lai-lain

4. Ada beberapa proses dalam pengolahan minyak bumi yaitu destilasi, cracking, alkilasi, reforming dan polimerisasi, treating serta blending.

5. Beberapa produk yang dihasilkan pada pengolahan minyak bumi yang bermanfaat, seperti bensin, minyak tanah, kerosin, gas, oli, parafin dan lain-lain.

6. Adapun dampak negatif dari minyak bumi adalah pemanasan Global, ekstraksi air, dan pencemaran perairan.

7. Dalam menimalisir dampak negatifdapat dilakukan penghematan dengan menggunakan bahan ramah lingkungan, menghemat energi semaksimal mungkin, memproduksi bensin bebas timbal, menproduksi bahan pengganti minyak bumi seperti bioetanol dan biodiesel dan lain-lain.

\section{REFERENSI}

[1] Hasanudin, M. 2005.TEKNOLOGI SEISMIK REFLEKSI UNTUK EKSPLORASI MINYAK DAN GAS BUMI. Vol. 30.

[2] Yulis, R., \& Zainul, R. 2018.DESAIN DAN KARAKTERISASI SEL SURYA SISTEM ELEKTRODA TEMBAGA (I) OKSIDA (Cu2O/Al) MODEL PIPA PADA LARUTAN NATRIUM SULFAT (Na2SO4) .

[3] Zuhra, Cut Fatimah. 2013.PENYULINGAN, PEMROSESAN DAN PENGGUNAAN MINYAK BUMI.

[4] Zainul, R., Oktavia, B., Dewata, I., \& Efendi, J. 1. 2018. Fabrication of hexagonal photoreactor indoor lights. IOP Conference Series: Materials Science and Engineering, Vol. 335.

[5] Halimatussadiah, Alin dan Resosodarma, Budy. 2004.TINGKAT EKSTRAKSI OPTIMAL MINYAK BUMI INDONESIA: APLIKASI MODEL OPTIMASI DINAMIKA., JURNAL EKONOMI DAN PEMBANHGUNAN INDONESIA, Vol. 5. 1.

[6] Nugroho, asatri.2009.PRODUKSI GAS HASIL BIODEGRADASI MINYAK BUMI:KAJIAN AWAL APLIKASINYA DALAM MICROBIAL ENHANCED OIL RECOVERY (MEOR). Vol. 3. 2

[7] Pertiwi E, , SrI, et al. 2011.Pemanfaatan Rumput Fimbrisylis sp. dalam Proses Bioremediasi Tanah pada Berbagai Konsentrasi Limbah Minyak Bumi., jurnal penelitian sains, Vol. 14. 1.

[8] Ramadhaon, Topan Maiza.2009. Pengaturan Production Sharing Contract Dalam Undang-Undang Minyak Dan Gas., Vol. 16.

[9] Marchanisyah, Chorry dan Novita, Dian. 2012.KEAKTIFAN BERPENDAPAT DENGAN MODEL PEMBELAJARAN DISKUSI STRATEGI BEACH BALL PADA MATERI POKOK MINYAK BUMI DAN GAS ALAM. Unesa Journal of Chemical Education, Vol. 1. 2. 
[10] Sucipta. 2009,.Penyimpanan Lestari Limbah Tenorm Dari Industri Minyak Dan Gas Bumi.Buletin Limbah, Vol. 13.

[11] Izana, Nyimas Nadya, Pandjaitan , Nurmala Katrina dan Sunito , Satyawan . 2015.PENGARUH KEKUASAAN TERHADAP PERILAKU UNJUK RASA MASYARAKAT DI SEKITAR INDUSTRI EKSTRAKTIF MINYAK BUMI., Sosiologi Pedesaan.

[12] Sari, E. S. J., \& Zainul, R. 2019. Nitrogen Triflorida (NF3) : Termodinamika dan Transpor Elektron NF3 ..

[13] Kristy, D. P., \& Zainul, R. 2019.Analisis Molekular dan Transpor Ion Natrium Silikat.

[14] Delvi, I. P., \& Zainul, R.2 019.Mercury (II) Nitrate (Hg(NO3)2): Interaksi Molekul dan Adsorpsi Hg dengan Karbon Aktif.

[15] Nugroho, A. 2006.Biomediasi Hidrokarbon Miinyak Bumi Cetakan I. Yogyakarta : Graha Ilmu,

[16] Surono, Untoro Budi dan Ismanto.2016,Pengolahan Sampah Plastik Jenis PP, PET dan PE Menjadi Bahan Bakar Minyak dan Karakteristiknya.Vol. 1.

[17] Dartanto, Teguh. 2005.BBM, Kebijakan Energi, Subsidi, dan Kemiskinan di Indonesia.

[18] Zainul, Rahadian, et al. 2015,MODIFIKASI DAN KARAKTERISTIK I-V SEL FOTOVOLTAIK CU2O/CU-GEL NA2SO4 MELALUI ILUMINASI LAMPU NEON. Eksakta, Vol. 2.

[19] Setiawati, Evy dan Edwar, Fatmir.1999.TEKNOLOGI PENGOLAHAN BIODIESEL DARI MINYAK GORENG BEKAS DENGAN TEKNIK MIKROFILTRASI DAN TRANSESTERIFIKASI SEBAGAI ALTERNATIF BAHAN BAKAR MESIN DIESELjurnal riset industri online,. Vol. 6. 2.

[20] Yasthopi, Arief, et al. 11, 2015.Photoelectrosplitting water for hydrogen production using illumination of indoor lights. Journal of Chemical and Pharmaceutical Research, Vol. 7, hal. 57-67 .

[21] Tri Atmaja, Bayu, Suhadak dan Hidayat, R. Rustam. 2016, ANALISIS PENGARUH TIMBAL BALIK EKSPOR IMPOR MINYAK DAN GAS TERHADAP PERTUMBUHAN EKONOMI INDONESIA Studi pada Bank Indonesia Periode 2006-2014. Jurnal Administrasi Bisnis (JAB), Vol. 31. 1.

[22] Zainul, R., Alif, A., Aziz, H., \&Arief, S. 2015.Disain Geometri Reaktor Fotosel Cahaya Ruang.Jurnal Riset Kimia, Vol. 8.

[23] Hatta, M, M.T, Emrizal dan Anita, S. 2013.Karakterisasi Dan Penentuan Kematangan Minyak Mentah ( Crude Oil Langgak , Riau. Prosiding Semirata FMIPA Universitas Lampung, Vol. 1(I), hal. 227-232. 
[24] Maypalita, F., M., \& Zainul, R. 2018.Pengaruh Penggunaan Lembar Kerja Siswa (LKS) Berbasis Inkuiri Terbimbing Pada Materi Larutan Penyangga Terhadap Hasil Belajar Siswa Kelas XI IPA SMAN 5 Padang .

[25] Mu in, Rosdiana. 2, 2010.UPAYA MEMPERPANJANG PEMAKAIAN MINYAK BUMI.Jurnal Teknik Kimia, Vol. 17, hal. 9-15.

[26] Purb, Jan Horas Veryady dan Hartoyo, Sri. Bandung .2018.DAMPAK KENAIKAN HARGA MINYAK BUMI TERHADAP PERMINTAAN CPO UNTUK BIODIESEL DAN BEBERAPA ASPEK PADA INDUSTRI KELAPA SAWIT INDONESIA., jurnal ilmia manajemen ekonomi, Vol. 9. 1 .

[27] Setiawati, Evy dan Edwar, Fatmir. 2012.TEKNOLOGI PENGOLAHAN BIODIESEL DARI MINYAK GORENG BEKAS DENGAN TEKNIK MIKROFILTRASI DAN TRANSESTERIFIKASI SEBAGAI ALTERNATIF BAHAN BAKAR MESIN DIESEL.Jurnal Riset Industri, Vol. IV, hal. 117-127.

[28] Probo, Endro. Gresik.IMPLEMENTASI KEBIJAKAN TANGGUNG JAWAB SOSIAL PADA INDUSTRI HULU MINYAK \& GAS BUMI.

[29] Nugroho, Hanan. 2004,PENGEMBANGAN INDUSTRI HILIR GAS BUMI INDONESIA: TANTANGAN DAN GAGASAN.Perencanaan Pembangunan No. IX.

[30] Hardeli, R Zainul and L P Isara. 2019. Preparation of Dye Sensitized Solar Cell (DSSC) using anthocyanin color dyes from jengkol shell (Pithecellobium lobatum Benth.) by the gallate acid copigmentation., Journal of Physics: Conference Series.

[31] Mulyanto, Adi. 1, 2018,PENGOLAHAN DAN PEMANFAATAN AIR LIMBAH INDUSTRI BIODIESEL. Jurnal Rekayasa Lingkungan, Vol. 5.

[32] Badrulfalah dan Irianingsih, Iin . 2018, SUB RUANG TUTUP TOPOLOGI HASIL KALI RUANG METRIK KERUCUT. EKSAKATA, Vol. 19.

[33] Sobirin, Miftah. 2006,ANALISA KEBIJAKAN INDUSTRI MINYAK DAN GAS BUMI: Studi Perbandingan Pada Kontrak Bagi Hasil Minyak Dan Gas Bumi di Indonesia dan Malaysia.Media Riset Akuntansi, Auditing dan Informasi, Vol. 6.

[34] Dartanto, T. 2005.BBM, kebijakan energi, subsidi dan kemiskinan di indonesia., Jurnal Inovasi, Vol. 5, hal. 3-10.

[35] Zainul, Rahadian. 2016, Design and Modification of Copper Oxide Electrodes for Improving Conversion Coefficient Indoors Lights (PV-Cell) Photocells.Der Pharma Chemica, Vol. 8, hal. 388-395.

[36] Fadah, Isti, Kristianto, Dayu dan Puspitasari, Novi. 2017.HARGA MINYAK BUMI DAN EMAS DUNIA SEBAGAI PENENTU PERGERAKAN 
INDEKS SEKTORAL DI BEI PERIODE 2011-2015., Ekuitas: Jurnal Ekonomi dan Keuangan, Vol. 1(IV), hal. 472-490.

[37] Febriani, S. S., Yolanda, T., Arianti, V. A., \&Zainul, R. 2018.A Review Solid Stated: principles and Methode.

[38] Casnan, irzaman dan Untoro, Pujdi.Efisien Energi Dari Tungku SekamDengan Kompor Bahan Bakar Campuran Air, MInyak Dan Gas Karbon Dengan Metode Kavitasi.

[39] Wahyuningsih, Asri, Sunarya, Yayan dan Aisyah, Siti. 2010,Metenamina Sebagai Inhibitor Korosi Baja Karbon Dalam Lingkungan sesuai kondisi pertambangan minyak Bumi. Jurnal Sains Dan Teknologi Kimia, Vol. 1. 1.

[40] Komarawidjaja, Wage. Jakarta.2009.KARAKTERISTIK DAN PERTUMBUHAN KONSORSIUM MIKROBA LOKAL DALAM MEDIA MENGANDUNG MINYAK BUMI.,jurnal teknologi liingkungan, Vol. 10. 1 .

[41] Putra, Arbie Marwan. 2010.Analisis Produktifitas Gas Hidrogen Dan Gas Oksigen Pada Elektrolisis Larutan KOH. Vol. 2.

[42] Zainul, R., Oktavia, B., Dewata, I., \& Efendi, J. 2017.Studi Dinamika Molekular dan Kinetika Reaksi pada Pembelahan Molekul Air untuk Produksi Gas Hidrogen .

[43] Zainul, Rahadian, et al.2019. Zinc/Aluminium-Quinclorac Layered Nanocomposite Modified Multi-Walled Carbon Nanotube Paste Electrode for Electrochemical Determination of Bisphenol A., Sensors, Vol. 19.

[44] Syafei, N. 1, 2018. ANALISIS FENOMENA KOROSI PELAT PIPA BAJA PADA KARBON API 5L-X65 DALAM LARUTAN 7900 ML AIR LAUT DAN 100 ML AMONIAK PADA KONDISI GAS CO2 DAN H2S JENUH PADA SUHU RUANG.,EKSAKTA : Berkala Ilmiah Bidang MIPA, Vol. 19.

[45] Parbuntari, H, et al. 2/30, 2018. Awal fitokimia Screening (Analisis Kualitatif) Kakao Daun ( Theobroma Awal fitokimia Screening (Analisis Kualitatif) Kakao Daun ( Theobroma Cacao L.).,Eksakta, Vol. 19.

[46] Husnah, Aulia Dinul dan Zainul, Rahardian. 2019Analisis Molekular dan Karakteristik Hidrogen Sianida (HCN)..

[47] Darmawan, Adi. Semarang.2004, HIDRORENGKAH FRAKSI BERAT MINYAK BUMI MENGGUNAKAN KATALIS LEMPUNG TERPILAR ALUMINIUM BERPENGEMBAN NIKEL. J. Kim. Sains \& Apl, Vol. 7. 1.

[48] Zainul, R. 2016.Effect of Temperature and Particle Motion against the ability of ZnO Semiconductor Photocatalyst in Humic Acid..

[49] Zainul, Rahadian dan Dewata, Indang. 2015.Determination of pH-BODCOD and degradation in batang arau watersheds at Padang city., Journal of Chemical and Pharmaceutical Research. 
[50] Zainul, R., Oktavia, B., Dewata, I., \& Efendi, J. 2018, Thermal and Surface Evaluation on The Process of Forming a $\mathrm{Cu} 2 \mathrm{O} / \mathrm{CuO}$ Semiconductor Photocatalyst on a Thin Copper Plate.IOP Conference Series: Materials Science and Engineering, Vol. 335.

[51] Widarsono, Bambang. Jakarta.2013.Cadangan dan Produksi Gas Bumi Nasional:Sebuah Analisis atas Potensi dan Tantangannya.

[52] Risdiyanta.MENGENAL KILANG PENGOLAHAN MINYAK BUMI (REFINERY)DI INDONESIA. 4, FORUM TEKNOLOGI, Vol. 05.

[53] Purwatiningsih, Annisa dan Masykur.2012.,EKSPLORASI DAN EKSPLOITASI PERTAMBANGAN MINYAK DAN GAS BUMI DI LAUT NATUNA BAGIAN UTARA LAUT YURIDIKSI NASIONAL UNTUK MENINGKATKAN KESEJAHTERAAN MASYARAKAT DI KEPULAUAN NATUNA.Vol. 2.

[54] Asyhar, Rayandra dan Nofrizal, jon. 2008.PENGARUH SUHU DAN WAKTU AKTIVASI TERHADAP KAPASITAS ADSORPSI KOKAS MINYAK BUMI., Vol. 1.

[55] Nandin. 2006.MINYAK BUMI DAN GAS.

[56] Crystiana, Indah, Susantoro, Tri Muji dan Firdaus, Nurus. 2015, Pengolahan Data Citra Satelit untuk Mengidentifi kasi Potensi Jebakan dalam Kegiatan Eksplorasi Migas. Vol. 49.

[57] Yanuar, F, Tillah, M dan Devianto. 2018,Pemodelan Indeks Pembangunan Manusia Menggunakan Ridge Metode Regresi.Vol. 19.

[58] Zainul, R, et al. 2018.Study of Internal Morphology on Preparation of Cu2OThinPlate using Thermal Oxidation ., Journal of Physics: Conference Series, Vol. 1116.

[59] Guci, S. R. F., Zainul, R., \& Azhar, M.2018.PENGEMBANGAN MEDIA PEMBELAJARAN BERBASIS TIGA LEVEL REPRESENTASI MENGGUNAKAN PREZI PADA MATERI KESETIMBANGAN KIMIA KELAS XI SMA/MA.

[60] Putri, Gusliani Eka, et al. 2018.Microstuctural Analysis and Optical Properties of Nanocrystalline Cerium Oxides Synthesized by Precipitation Method.

[61] Hidayani, T. 1, 2018.GRAFTING POLIPROPILENA DENGAN MALEAT ANHIDRIDA SEBAGAI PENGIKAT SILANG DENGAN INISIATOR BENZOIL PEROKSIDA., EKSAKTA : Berkala Ilmiah Bidang MIPA, Vol. 19.

[62] Yanti, C. F., \& Zainul, R. 2019.Ba(OH)2 : Transpor Ionik pada Barium Hidroksida di dalam Air dengan Konsep Termodinamika . 
[63] Cheva, V. K., \& Zainul, R. 1, 2019.Pengembangan e-modul berbasis inkuiri terbimbing pada materi sifat keperiodikan unsur untuk SMA/MA kelas x., EduKimia, Vol. 1.

[64] Azhar, M., Ahda, Y., Ihsanawati, I., Puspasari, F., Mawarmi, S., Risa , B. and Natalia, D. 2019.SKRINING BAKTERI PENDEGRADASI INULIN DARI RIZOSFER UMBI DAHLIA MENGGUNAKAN INULIN UMBI DAHLIA. EKSAKTA : Berkala Ilmiah Bidang MIPA, Vol. 18.

[65] Jumalia, R., \& Zainul, R.2019.Natrium Karbonat : Termodinamika dan Transport Ion..

[66] R, Ruswandi.2018.Determination Of Fructose Content Resulted By Inullin Hydrolisis With Dns As Oxidizer ., EKSAKTA, Vol. 19.

[67] Hidayat, D. 2018.Analisis Respon Pengontrol On-Off Pada Kendali Umpan Balik Sistem Fisis Elektronik. EKSAKTA : Berkala Ilmiah Bidang MIPA, Vol. 19.

[68] Syafmen, Wardi, Febriyanti, Azzikra dan Multahadah, Cut. 2018.ANALISIS KLASIFIKASI AKREDITASI SMA/MA BERDASARKAN FAKTORFAKTOR YANG MEMPENGARUHI SE PROVINSI JAMBI DENGAN RLTOG., EKSAKTA : Berkala Ilmiah Bidang MIPA, Vol. 19.

[69] Joebaedi, K. 1, 2018.Model Star (1;1) Pada Data Produktivitas Teh, EKSAKTA: Berkala Ilmiah Bidang MIPA, Vol. 19.

[70] Ramalisa, Y., Febriyanti, A. and Multahadah, C. 2019.Analysis of Non Hierarchical Bomb for Collection of Community Health Degrees in Jambi and Muaro Jambi City”.EKSAKTA : Berkala Ilmiiah Bidang MIPA, Vol. 20.

[71] Alfionita, T., \& Zainul, R. 2019.Calcium Chloride (CaCl2) : Characteristics and Molecular Interaction in Solution .

[72] Hakimi, A., \& Zainul, R.2019.Asam Arsenat (H3AsO4): Analisis Molekular dan Karakteristik Senyawa..

[73] Zainul, R. 2016.Studi Literasi Menggunakan Endonote Dan Aplikasi Pembantu (Google Translator, Google Cendekia, Google Sites Dan Chemoffice 2008, E-Leraning Dan Snipping Tool).

[74] Sanjaya, Andryan Arief, Koeswahyono, Imam dan i Qurbani, Indah Dw.PENGATURAN KEWENANGAN PEMERINTAH DAERAH DALAM KEGIATAN USAHA HULU MINYAK DAN GAS BUMI DI WILAYAH LAUT.

[75] Qurbani, Indah Dwi. Malang.2012.POLITIK HUKUM PENGELOLAAN MINYAK DAN GAS BUMI: DI INDONESIA., Vol. 6. 2.

[76] Retno Susmiyati, Haris. Samarinda.2006, ASPEK HUKUM KONTRAK BAGI HASI DALAM PENGUSAHAN PERTAMBANGAN MINYAK DAN GAS BUMI DI INDONESIA. Vol. 2. 2. 
[77] Putri, D., Anika, M. and Wahyuni, W. 2019. ioinformatics Study Genes Encoding Enzymes Involved in the Biosynthesis of Carotenoids Line Cassava (Manihot esculenta).EKSAKTA, Vol. 20.

[78] Kartikasari, Dewi, Nurjazuli dan Rahardjo, Mursid. 2016.ANALISIS RISIKO KESEHATAN PAJANAN BENZENE PADA PEKERJA DI BAGIAN LABORATORIUM INDUSTRI PENGOLAHAN MINYAK BUMI. Vol. 4.

[79] FEUI, B.R.L. 2010.analisis industri minyak dan gas di indonesia .

[80] Putri, D., Fifendy, M. and Putri, M. 1, 2018, DIVERSITAS BAKTERI ENDOFIT PADA DAUN MUDA DAN TUA TUMBUHAN ANDALEH (Morus macroura miq).EKSAKTA : Berkala Ilmiah Bidang MIPA, Vol. 19.

[81] Prabowo, H. 1, 2018,PENYELIDIKAN KELAYAKAN KIMIA DAN PENYEBARAN CADANGAN PASIR BESI DAERAH TIKU KABUPATEN AGAM UNTUK BAHAN BAKU SEMEN PADA PT. SEMEN PADANG.EKSAKTA : Berkala Ilmiah Bidang MIPA, Vol. 19.

[82] Syafriadiman, Huri, Eryan dan Harahap, Sampe. 2009, Toksitas Limah Cair Minyak Bumi Terhadap Benih Kerapu Bebek (Cromileptis altivelis).Terubuk, Vol. 37, hal. 93-102.

[83] Andarani, Pertiwi dan Rezagama, Arya . 2015,ANALISIS PENGOLAHAN AIR TERPRODUKSI DI WATER TREATING PLANT PERUSAHAAN EKSPLOITASI MINYAK BUMI (STUDI KASUS: PT XYZ).Presipitasi, Vol. 12.

[84] P, Oki Marlina, et al. 2018.Grinding : Teknik dan Prinsip Dasar pada Pengolahan Material

[85] Chatri,M., Mansyurdin, M.,Bakhtiar, A. and Adnadi, P. 2017.PERBANDINGAN KOMPONEN MINYAK ATSIRI ANTARA DAUN MUDA DAN DAUN DEWASA PADA HYPTIS SUAVEOLENS (L.)POIT., EKSAKTA : Berkala Ilmiah Bidang MIPA, Vol. 18.

[86] Izana, Nyimas Nadya, Pandjaitan, Nurmala Katrina dan Sunito, Satyawan.PENGARUH KEKUASAAN TERHADAP PERILAKU UNJUK RASA MASYARAKAT DI SEKITAR INDUSTRI EKSTRAKTIF MINYAK BUMI., Vol. 03. 01.

[87] Junica Utami, Venny. 2018,Pengaruh Rasio Profitabilitas Terhadap Nilai Perusahaan Pada Industri Minyak dan Gas Bumi yang Terdaftar di Bursa Efek Indonesia Periode 2012 - 2016. Jurnal Ilmiah Ekonomi dan Bisnis, Vol. 9. 1.

[88] Hasibuan, wisnu Rama Pradika, Susmiyati, Haris Retno dan Syariffuddin, la. 2014,Perandingan Hukum Pengusaan Dan Pengusahan Minyak Dan Gas Bumi Di Indonesia. Vol. 3. 
[89] Husna TR, Cut Asmaul.KONTRIBUSI DANA BAGI HASIL MINYAK DAN GAS BUMI TERHADAP ANGGARAN PENDAPATAN BELANJA KABUPATEN (APBK) ACEH UTARA KAITANNYA DENGAN KEMISKINAN., Vol. 3.

[90] Harun, Jahriza. Riau.2009,PERMASALAHAN MINYAK DAN GAS (MIGAS) DI RIAU.Jurnal Ekonomi.Volume, Vol. 17. 3.

[91] Chaidir, z., Fadjria, N., A., \& Zainul, R. 2018.ISOLATION AND MOLECULAR IDENTIFICATION OF FRESHWATER MICROALGAE IN MANINJAU LAKE WEST SUMATERA.

[92] Suratno, T., Rarasati, N. and Z G.2019,Optimization of Genetic Algorithm for Implementation Designing and Modeling in Academic Scheduling.EKSAKTA : Berkala Ilmiah Bidang MIPA, Vol. 20.

[93] Pasaribu, F., Mardia, A. and Sormin, C. 2019.Ordinal Logistic Regression with an Application to Health Service Quality in Raden Mattaher Jambi Hospital., EKSAKTA : Berkala Ilmiah Bidang MIPA, Vol. 20.

[94] Khairani, Yuniarti, Elsa dan Sumarmin , Ramadhan .2018, PENGARUH EKSTRAK KULITBUAH MANGGIS (GARCINIA MANGOSTANA L.) TERHADAP HISTOLOGIS PANKREAS MENCIT (MUS MUSCULUS L. SWISS WEBSTER) YANG DIINDUKSI SUKROSA. EKSAKTA : Berkala Ilmiah Bidang MIPA, Vol. 19.

[95] Putri, D. F., Ritonga, H. M., Murdiati, V., \& Zainul, R. 2018.WHAT IS HYDROTHERMAL?

[96] Samah, S. 2, 2017. karakteristik Plstik Boidegradabel dari LDEP-g-MA dan Pati tandan Kosong sawit . EKSAKTA: Berkala Ilmiah Bidang MIPA.VOL 18

[97] Joebaedi, K., Susanti, D., Warwah, N., Parmikanti, K. and Badrulfalah, B.2019, Some Properties of Green's Matrix of Nonlinear Boundary Value Problem of First Order Differential. EKSAKTA : Berkala Ilmiah Bidang MIPA, Vol. 20.

[98] Zam, Syukria Ikhsan. 2010,OPTIMASI KONSENTRASI INOKULUM BAKTERI HIDROKARBONOKLASTIK PADA BIOREMEDIASI LIMBAH PENGILANGAN MINYAK BUMI DI SUNGAI PAKNING . Ilmu Lingkungan, Vol. 4.

[99] Ikhsan Zam, Syukria.2010.PROSES BIOREMEDIASI LIMBAH PENGILANGAN MINYAK BUMI MENGGUNAKAN KULTUR CAMPURAN., Vol. 1. 2.

[100]Nasional, D.E. 2014, Outlook Energi Indonesia 2014. Jakarta: Dewan Energi Nasional. 
[101]Roziqin. 2015.PENGELOLAAN SEKTOR MINYAK BUMI DI INDONESIA PASCA REFORMASI: ANALISIS KONSEP NEGARA KESAJHTERAAN .

[102]Sutanto, Kevin. Bandung. 2016.Teknologi Membran dalam Pengolahan Gas Alam.

[103]Sundaryono, Agus dan Budiyanto. 2010.PEMBUATAN BAHAN BAKAR HIDROKARBON CAIR MELALUI REAKSI CRACKING MINYAK PADA LIMBAH CAIR PENGOLAHAN KELAPA SAWIT. Vol. 20.

[104]Welyyanti, D. 2018,BEBERAPA SYARAT CUKUP UNTUK BILANGAN KROMATIK LOKASI HINGGA PADA GRAF TAK TERHUBUNG.EKSAKTA: Berkala Ilmiah Bidang MIPA, Vol. 19.

[105]Darmawan , Adi . 2004.Hidrorengkah Fraksi Berat Minyak Bumi Menggunakan Katalis Lempung Terpilar Aluminium Berpengemban Nikel., Jurnal Kimia Sains Dan Aplikasi, Vol. 7, hal. 6-10.

[106]Joebaedi, K, Parmikanti , K dan Badrulfalah .2018.Orde Pertama Space Time Autoregressive Stationary Model pada Data Petroleum.,Eksakta, Vol. 19.

[107]Surono, Untoro Budi. Yogyakarta.2013.BERBAGAI METODE KONVERSI SAMPAH PLASTIK MENJADI BAHAN BAKAR MINYAK.,JURNAL TEKNIK, Vol. 3. 1.

[108]Kurniawan, , Andre Dwiky, Semin dan Suprajitno, Tjoek.2014, Analisis Penggunaan Bahan Bakar Biothanol Dari Batang Padi Sebagai Campuran Pada Bensi. JURNAL TEKNIK POMITS, Vol. 3.

[109]iza, Y. M., Yasin, R. C., Maidani, S. S., \& Zainul, R. 2018.SOL GEL : PRINCIPLE AND TECHNIQUE. L

[110]Raharjo, Wahyu Purwo. Surakart. 2009,PEMANFAATAN OLI BEKAS DENGAN PENCAMPURAN MINYAK TANAH SEBAGAI BAHAN BAKAR PADA ATOMIZING BURNER.Vol. 10.

[111]Santoso, Budy. 1, 2018.Identifikasi Akuifer Menggunakan Metode Geolistriks Raesistivitas Di Daerah Bebandem, Karang Asem ,Bali. EKSAKTA: Berkarya Ilmiah Bidang MIPA,VOL19

[112]Lumbantoruan, Parmin dan Yulianti, Erislah.2016,PENGARUH SUHU TERHADAP VISKOSITAS MINYAK PELUMAS (OLI). Vol. 3.

[113]Effendi, M. Syafwansyah dan Adawiyah, Rabiatul.2014. Jurnal INTEKNA.

[114]Hanoum, Syarifah, et al. Surabaya.PERANCANGAN MODEL PENGEMBANGAN KINERJA DAYA SAING KLASTER INDUSTRI MINYAK DAN GAS BUMI DI JAWA TIMUR.

[115]Yudono, Bambang dan Estuningsi, Sri Pertiw.2013.Kinetika Degradasi Limbah Minyak Bumi Menggunakan Sinergi Bakteri Konsorsium 
(Microccoccus sp, Pseudomonas pseudomallei, Pseudomonas pseudoalcaligenes dan Bacillus sp) dan Rumput Eleusine Indica (L.) Gaertn.

[116]Hartiniati.2006.Hidrokonversi Katalitik Residu Minyak Bumi: Pengaruh Temperatur Dan Waktu Reaksi., Reaktor, Vol. 10, hal. 82-87.

[117]HARTINIATI. 2006.HIDROKONVERSI KATALITIK RESIDU MINYAK BUMI: PENGARUH TEMPERATUR DAN WAKTU REAKSI., Vol. 10.

[118]Zainul, R., Oktavia, B., Nasra, E., Arianti, V. A., Fatimah, P., Liza, Y. M., \& Setiadi, T. 2018.Studi Pengembangan dan Efektivitas Model Penulisan Karya Ilmiah berbasis Online Data dengan menggunakan Aplikasi Endnote bagi Guru-guru MGMP Kimia Kota Padangpanjang .

[119] Dinata, Agil Aditya, et al. 2018.CHEMICAL VAPOR DEPOSITION : PROCESS AND APPLICATION .

[120]Syafei , Nendi Suhendi, et al. 2018. Analisis Cracking Korosi pada Pipa Baja Karbon API 5LX65 di Solution $7700 \mathrm{ml}$ aquades, $250 \mathrm{ml}$ asam asetat dan $50 \mathrm{ml}$ Amonia dengan Gas CO $27700 \mathrm{ml}$ aquades, $250 \mathrm{ml}$ asam asetat dan $50 \mathrm{ml}$ Amonia dengan Gas CO 2 dan H 2 S di Kondisi Saturasi., Eksakta, Vol. 19.

[121] Rizki Saputra ,Mand Sumarmin,R. 2018,PENGARUH EKSTRAK DAUN SIRIH MERAH (Piper crocatum Ruiz \& Pav.) TERHADAP GLUKOSA DARAH MENCIT (Mus musculus L.) JANTAN YANG DIINDUKSI SUKROSA. EKSAKTA : Berkala Ilmiah Bidang MIPA, Vol. 19.

[122]Sanjaya, H. 2, 2017,DEGRADASI METHYLENE BLUE MENGGUNKAN KATALIS ZnO-PEG DENGAN METODE FOTOSONOLISIS. EKSAKTA: Berkala Ilmiah Bidang MIPA, Vol. 18.

[123]Shafitri, M., \& Zainul, R. 2019.Vanadium Pentaoksida (V2O5) : Termodinamika Molecular dan Interaksi Ion dalam Larutan .

[124]Rahmadhanty, S., \& Zainul, R. 2018.DESIGN OF HUMAT ACID SOLID SOLUTION REACTOR THROUGH PHOTOTRANSFORMATION OF COPPER OXIDE $(\mathrm{CuO})$ SEMICONDUCTOR PLATE.

[125]Zainul, R., Effendi, J., \& Mashuri, M. 2, 2019,Phototransformation of Linear Alkylbenzene Sulphonate (LAS) Surfactant Using ZnO-CuO Composite Photocatalyst. KnE Engineering, Vol. 1, hal. 235-247.

[126]Utami, Lucky Intrati, et al. 2017,Pengolahan Limbah Cair Minyak Bumi Secara Biologi Aerob Proses Batch. Teknik Kimia, Vol. 11.

[127] Sari, M., \& Zainul, R. 2018.Kalium Dikromat (K2Cr2O7) Spektroskopi dan Transpor K2Cr2O7 .

[128]Aumi, V., M., \& Zainul, R.2018.Pengembangan Bentuk Lembar Kerja Siswa (LKS) untuk Aktivitas Kelas dan Laboratorium Berbasis Inkuiri Terbimbing pada Pokok Bahasan Laju Reaksi . 
[129]Sucipta. Batan .PENYIMPANAN LESTARI LIMBAH TENORM DARI INDUSTRI MINYAK DAN GAS BUMI.

[130]Fatimah, Putri, et al. 2018.A REVIEW Teknik Blended : Prinsip dan DasarDasar..

[131]Fitridawati, Putri, Lusi Dwi dan Dinata, Marta . 2019 .The Study Trees Potential for Forest in Universitas Lancang Kuning Pekanbaru., EKSAKTA : Berkala Ilmiah Bidang MIPA, Vol. 20.

[132]Harahap , Fatma Suryani dan Lubis , Laila Tussifah. 2018.Analysis of Heavy Metals Distribution in the River Town of Hamasaki's Rod Padang Sidimpuan. EKSAKTA : Berrkala Ilmiah Bidang MIPA, Vol. 19.

[133]Suhaemi, Zasmeli , et al. 1, 2019.The Study of African Leave (Vernonia amygdalina) in for Improving the Quality of Local Duck Meats of West Sumatera., EKSAKTA : Berkala Ilmiah Bidang MIPA, Vol. 20.

[134]Asmara, Alla, et al. 2016.VOLATILITAS HARGA MINYAK DUNIA DAN DAMPAKNYA VOLATILITAS HARGA MINYAK DUNIA DAN DAMPAKNYA MAKROEKONOMI INDONESIA. Jurnal Agro Ekonomi, Vol. 29.

[135]Yurmaniati dan Zainul, Rahadian. 2018.SILVER SULFATE (Ag2SO4):MOLECULAR ANALYSIS AND ION TRANSPORT.

[136]Prayogo, Dody. jakarta.2011, EVALUASI PROGRAM CORPORATE SOCIAL RESPONSIBILITY DAN COMMUNITY DEVELOPMENT PADA INDUSTRI TAMBANG DAN MIGAS. Vol. 15. 1.

[137]PRAYITNO, JOKO. 2017, Ujicoba Konsorsium Mikroba dalam Upaya Bioremediasi Tanah Tercemar Minyak dengan Menggunakan Teknik Landfarming Skala Bangku. Jurnal Teknologi Lingkungi, Vol. 18.

[138]Prijambada, Irfan D. dan WIDADA, JAKA.2006.MITIGASI DAN BIOREMEDIASI LAHAN TAMBANG MINYAK.

[139] Charlena, et al.2009.PROFIL KELARUTAN LIMBAH MINYAK BUMI DALAM AIR AKIBAT PENGARUH SURFAKTAN NONIONIK DAN LAJU PENGADUKAN.

[140]Munawar dan Zaidan.2013.Bioremediasi Limbah Minyak Bumi dengan Teknik Biopile di Lapangan Klamono Papua., Sains Dan Matemmatika, Vol. 1. 2.

[141]Noviana, Horiza , Hevi dan Kusuma, Gina Dwi Nur. 1, 2018.PENGARUH PENGGUNAAN KARBON AKTIF AMPAS TEBU TERHADAP PENURUNAN SALINITAS PADA SUMUR GALI DI RT 003 RW 006 KELURAHAN TANJUNG UNGGAT KOTA TANJUNGPINANG TAHUN 2017., EKSAKTA : Berkala Ilmiah Bidang MIPA, Vol. 19. 
[142]Cahyani, Asti May, Busyairi, Muhammad dan Nurdiana,2018.Identifikasi Timbulan Limbah Sludge Oil dari Kegiatan Eksploitasi Dan Produksi Minyak dan Gas Bumi PT. AMC., Prosiding Seminar Nasional XII.

[143]Aries Rokhmana, Catur. Yogyakartai, 2012.POTENSI PEMANFAATAN PENGINDERAAN JAUH DENGAN WAHANA UDARA NIR-AWAK DI INDUSTRI TAMBANG DAN MIGAS.

[144]Cahyono, waluyo eko. 2010, pengaruh pemanasan global terhadap lingkungan bumi. berita dirgantara, Vol. 8. 2.

[145]Hidayati, R., \& Zainul, R.2019.Studi Termodinamika Transpor Ionik Natrium Klorida Dalam Air dan Campuran Tertentu .

[146] Izana, Nyimas Nadya, Pandjaitan, Nurmala Katrina dan Sunito, Satyawan. 2013.PENGARUH KEKUASAAN TERHADAP PERILAKU UNJUK RASA MASYARAKAT DI SEKITAR INDUSTRI EKSTRAKTIF MINYAK BUMI.

[147]Yulia, Lusiana Riski, Marsa, Bindanetty dan Julliastuti, sri Rachmania. Surabaya: s.n., 2012.Bioremedasi Ail Laut Terkontamasi Minyak Bumi Dengan Menggunakan Bakteri Pseudomonas Aeruginosa. Institut Teknologi Sepuluh Nopember.

[148]Aliyanta, Barokah, Sumarlin, La Ode dan Mujab, Ahmad Saepul.2011.Penggunaan Biokompos dalam Bioremediasi Lahan Tercemar Limbah Minyak Bumi.Vol. 2.

[149]Badrun, Yeeri. 2008Analisis Kualitas Perairan Selat Rupat Sekitar Aktivitas Industri Minyak Bumi Kota Dumai., Ilmu Lingkungan, Vol. 1.

[150]FAJAR, M SIDIQ. MARITIM .2011,ANALISA PENGENDALIAN LAJU KOROSI PADA PIPA MINYAK BUMI LEPAS PANTAI. JURNAL SAINS DAN TEKNOLOGI, Vol. 10. 1.

[151]Santosa, Joko. 2014.PENGARUH KENAIKAN HARGA MINYAK MENTAH TERHADAP PEMANFAATAN BIO-DIESEL DAN DAMPAK LINGKUNGAN.. 